\title{
The Impact of Urban Transit Systems on Property Values: A Model and Some Evidences from the City of Naples
}

\author{
Mariano Gallo \\ Dipartimento di Ingegneria, Università del Sannio, Piazza Roma 21, 82100 Benevento, Italy \\ Correspondence should be addressed to Mariano Gallo; gallo@unisannio.it
}

Received 9 October 2017; Revised 30 January 2018; Accepted 21 February 2018; Published 5 April 2018

Academic Editor: David F. Llorca

Copyright (C) 2018 Mariano Gallo. This is an open access article distributed under the Creative Commons Attribution License, which permits unrestricted use, distribution, and reproduction in any medium, provided the original work is properly cited.

\begin{abstract}
A hedonic model for estimating the effects of transit systems on real estate values is specified and calibrated for the city of Naples. The model is used to estimate the external benefits concerning property values which may be attributed to the Naples metro at the present time and in two future scenarios. The results show that only high-frequency metro lines have appreciable effects on real estate values, while low-frequency metro lines and bus lines produce no significant impacts. Our results show that the impacts on real estate values of the metro system in Naples are significant, with corresponding external benefits estimated at about 7.2 billion euros or about $8.5 \%$ of the total value of real estate assets.
\end{abstract}

\section{Introduction}

Urban transit systems play a fundamental role for the social and economic development of large urban areas, as well as significantly affecting the quality of life in such areas. Mobility and accessibility are two important factors that influence everyday life, social inclusion, and the competitiveness of firms and commercial operators. The quality of urban transit systems also affects real estate values: the higher the quality and quantity of transit system services in an urban area, the higher the active and passive accessibility of the area, and the higher the average real estate values.

When a public authority invests in transportation infrastructures and/or in transit services, it generates some external (or social) costs and benefits; a cost [benefit] is considered "external" if it is produced by subject A and borne [enjoyed] by subject $B$, without any compensation between the subjects [1-3]. Usually, the external costs of transportation are associated with air pollution, greenhouse gas emissions, noise, accidents, and congestion. While there is extensive literature on such external costs [4-8] which are nowadays taken into account in some transportation planning processes, less attention is devoted to external benefits that are hardly ever explicitly considered in economic and social analyses of transport investments. Besides the high direct benefits due to improved accessibility, reduced generalised trip costs, and the lower environmental impacts produced by less use of private cars, investments in transit systems, especially in railways and metros, may generate an appreciable increase in property values in the zones served; this benefit should be explicitly considered inside cost-benefit analyses. Note that even if the increases in property values mainly regard most of the users that live near rail stations, they have to be considered external benefits since they are enjoyed by all property owners, regardless of whether they use the transit system or live near the stations. In terms of social equity, especially if there are major differences between the transit supply in different urban areas, an evident disequilibrium is created; indeed, some inhabitants have available a high level-of-service transit system and, moreover, if property owners, also a benefit on the value of their properties. On the other hand, people living in areas not served by good quality transit systems suffer a double disadvantage: on transportation systems and property values. Since transit systems are subsidised strongly with public money and, then, by the whole society, a more equitable transit supply should be an important objective of transport policy. This imbalance can in part be compensated by introducing local taxes on property [9]. Another aspect of the problem is related to the optimal taxation in the presence of (positive or negative) externalities; this topic is outside the aims of this paper, but the reader may refer to Cremer et al. [10], Auerbach and Hines [11], and Christiansen and Smith [12]. 
In order to consider explicitly in transportation planning the impacts of transit system investments on real estate values as external benefits, we need to estimate the hedonic price of the presence of transit systems. According to hedonic theory [13], it is assumed that the price of a complex good, such as a house, can be expressed as a function of its extrinsic and intrinsic attributes: the coefficient of each attribute represents its implicit (hedonic) price. Calibration of hedonic pricing models, taking the availability of transit systems into explicit consideration, allows us to estimate the hedonic price of the presence of such systems in an area or in proximity to an area.

In the literature, much evidence can be found of the impact of transit system availability on real estate values. Obviously, most papers refer to specific case studies since it is very difficult to generalise models and analyses. Almost all research findings have underlined a positive correlation between the availability of transit systems (nearby) and property values, especially with respect to high-quality systems, whether railways [14-26] or bus rapid transit lines [19, 27-30]. Fewer have also studied the negative effects of transit system proximity [31, 32], due to externalities (mainly noise). Brandt and Maenning [33] and Szczepańska et al. [34], instead, studied the influence of road noise on real estate values. Interesting meta-analyses were proposed by Mohammad et al. [35], examining 102 estimates from 23 studies for the impact of rail projects on land and property values, and by Debrezion et al. [25].

From the modelling point of view, almost all papers propose hedonic price models (HPMs) for estimating property values and their correlation with transit system availability. Regarding the functional forms of the models in question, several types have been proposed: multiple linear regression (MLR) models [13, 14, 30, 31, 36, 37], also with a semilogarithmic form [16-18, 22, 23, 33, 38]; a multilevel model was proposed by Cervero and Kang [27], a quantile regression model was by Bohman and Nilsson [15], a Box-Cox linear transformation regression was by Chen and Haynes [16], a cross-sectional model was by Sun et al. [22], spatial econometric models were by Ibeas et al. [36], Efthymiou and Antoniou [32], Chen and Haynes [16], and Mulley et al. [19], a DID (Difference-in-Differences) estimator was by Dubé et al. [26], random utility models were by Jun [29], and a spatial Durbin model was by Zhong and Li [24].

This paper proposes a (nonspatial) hedonic model for evaluating the impacts of urban transit systems on property values. In the literature, numerous spatial hedonic models can be found [39-43] that may be able to improve the results, but their application requires very small zones or, at the limit, single buildings; as will be described in the following, the available zoning is not suitable for the application of this approach. Other approaches proposed in the literature require more detailed data that are not available for the case study in the object.

The main objectives of this paper are (i) to estimate the impacts of transit systems on real estate values in the city areas; (ii) to evaluate the corresponding external benefits; (iii) to evaluate the effects of some interventions on the Naples metro system on real estate values and on the corresponding external benefits for the areas concerned.
The remainder of the paper is organised as follows: in Section 2 the case study and the data used are described; in Section 3 the data are analysed and the hedonic model is formulated and calibrated; the impacts on real estate values and on the corresponding external benefits are estimated in Section 4; some analyses of two future scenarios are reported in Section 5; Section 6 concludes the paper.

\section{Case Study and Data}

The main objective of this paper is to estimate the impact of transit systems on real estate values in the city of Naples (Italy) and to evaluate the corresponding external benefits. The proposed approach can be applied, with the necessary modifications, to other large towns and cities. Naples is the largest city in southern Italy with about one million inhabitants (962,003 at the last census). It is the capital of the region of Campania and is close to some of the world's best known tourist destinations. Naples and its metro system were recently studied by Pagliara and Papa [20] who evaluated the impact of metro investments on property values and residents' location, analysing the changes produced by the opening of new stations with a pre- and postanalysis in the zones affected. In this paper, instead, we propose a model applicable to the whole city for estimating the impact of transit systems on property values and we explicitly estimate the external benefits produced by the presence of a metro system.

For the aims of this paper, three kinds of data were required:

(i) census data on population, density, quality of buildings, number and area (in $\mathrm{m}^{2}$ ) of buildings, retail businesses;

(ii) real estate values;

(iii) transit system data.

All census data were obtained from the Italian National Institute of Statistics (ISTAT) and refer to the last national survey [44]. The available data are aggregated into 4,307 census subzones (see Figure 1). The data that we used in our model were resident population, density, number of residential buildings classified by state of conservation (very good, good, medium, and poor), total area of residential buildings, and retail employees (as a proxy of retail businesses in the city zones).

Real estate values were obtained from the Real Estate Market Observatory (OMI) [45], which is a database provided by the Italian Revenue Agency about real estate values in all Italian cities, subdivided by homogeneous zones. In this database, Naples is partitioned into 65 zones, as reported in Figure 2; the dimensions of the zones are not compatible with the use of spatial hedonic models. For each OMI zone, the database provides some data; in our study we refer to the following data: (a) minimum and maximum real estate values for residential buildings in a normal state of conservation; (b) kind of zone (central, semicentral, peripheral, suburban, and rural). The median real estate values for OMI zones are summarised in Figure 3; the classes of zones are reported in Figure 4. From the database of OMI zones, we eliminated five zones (R1, R2, D28, D31, and E41) for which no real estate 


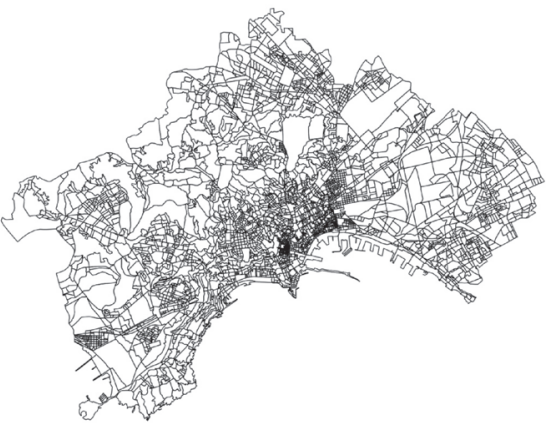

Figure 1: Census zones [44].

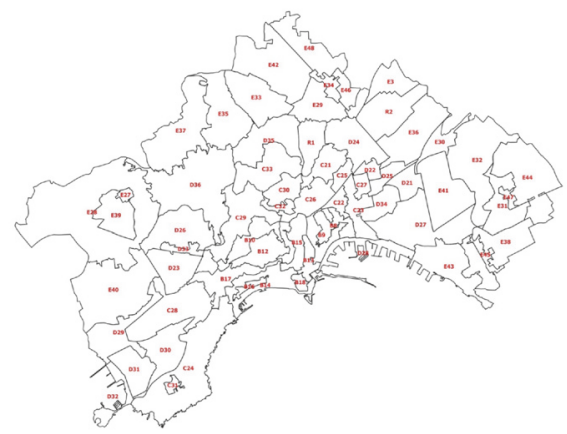

FIgURe 2: OMI zones [45].

values were associated, since there were too few real estate sale contracts to be statistically significant or they were not present. Therefore we refer to a database of $60 \mathrm{OMI}$ zones.

Data on the transit supply system were collected directly from the operators and involved the following services:

(i) 4 funiculars (Centrale, Chiaia, Montesanto, and Mergellina);

(ii) 7 metro lines (Line 1, Line 2, Cumana, Circumflegrea, and 3 Circumvesuviana lines);

(iii) 76 bus lines.

In Table 1, the list of railway lines with the corresponding average daily frequencies is reported. In Table 2, the average daily frequencies of bus lines are summarised. It can be noted that average bus line frequencies are very low for urban services, except for a few lines; it is due to a strong financial crisis suffered in the last decade by the municipality that owns the urban bus firm and by the region that finances the largest part of transit services. The metro and bus lines are illustrated in Figures 5 and 6, respectively. Figure 5 also shows the metro lines currently under construction (black lines).

This case study is very appropriate for the proposed analysis since the Naples transit system covers the various areas of the city with very different levels of service: (a) some zones are served by medium/high-frequency metro lines or funiculars, besides some bus services; (b) other zones are served by lowfrequency metro lines, besides some bus services; (c) some zones are served only by low-frequency bus lines; (d) some

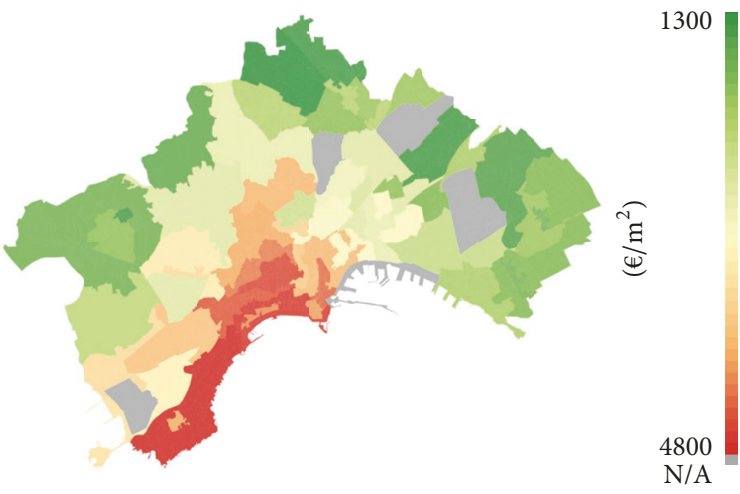

Figure 3: Median real estate values.

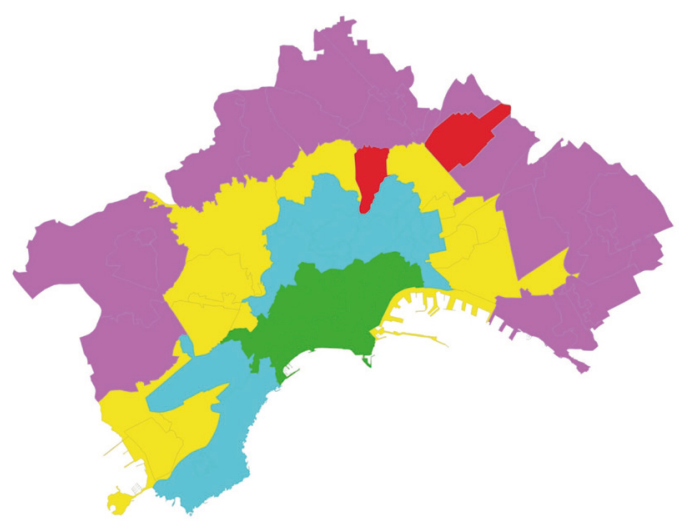

Rural

Suburban

Peripheral

FIgURE 4: Classification of OMI zones.

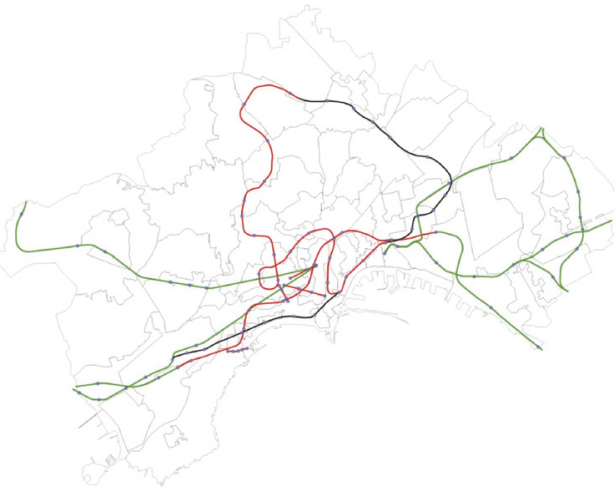

— High freq

_ Low freq

— Under construction

Figure 5: Metro network. 
TABLE 1: Railway lines.

\begin{tabular}{lccc}
\hline Line & From-to & Service time and headways & Average daily frequency [train/h] \\
\hline Line 1 & Garibaldi-Piscinola & $6: 20-6: 40\left(20^{\prime}\right)$ & $7: 40-21: 44\left(8^{\prime}\right)$ \\
& & $21: 44-23: 02\left(14^{\prime}\right)$ & 7.00 \\
\hline Line 2 & Pozzuoli-Gianturco & $5: 20-23: 20\left(8^{\prime}\right)$ & 7.50 \\
\hline Cumana railway & Montesanto-Torregaveta & $5: 21-22: 30\left(20^{\prime}\right)$ & 3.00 \\
\hline Circumflegrea railway & Montesanto-Torregaveta & $5: 12-21: 43\left(20^{\prime}\right)$ & 3.00 \\
\hline & Napoli-Sorrento & $6: 09-21: 39\left(28^{\prime}\right)$ & 2.14 \\
& Napoli-Baiano & $6: 04-20: 18\left(26^{\prime}\right)$ & 2.31 \\
Circumvesuviana railway (suburban) & Napoli-Sarno & $6: 32-20: 02\left(39^{\prime}\right)$ & 1.54 \\
& Napoli-Poggiomarino & $5: 55-19: 55\left(36^{\prime}\right)$ & 1.67 \\
\hline “Central" funicular & Napoli-San Giorgio & $6: 11-18: 11\left(36^{\prime}\right)$ & 1.67 \\
\hline "Chiaia" funicular & Augusteo-Piazza Fuga & $6: 30-00: 30\left(10^{\prime}\right)$ & 6.00 \\
\hline "Montesanto" funicular & Parco Margherita-Cimarosa & $6: 30-00: 30\left(10^{\prime}\right)$ & 6.00 \\
\hline "Mergellina" funicular & Montesanto-Morghen & $7: 00-22: 00\left(10^{\prime}\right)$ & 6.00 \\
\hline
\end{tabular}

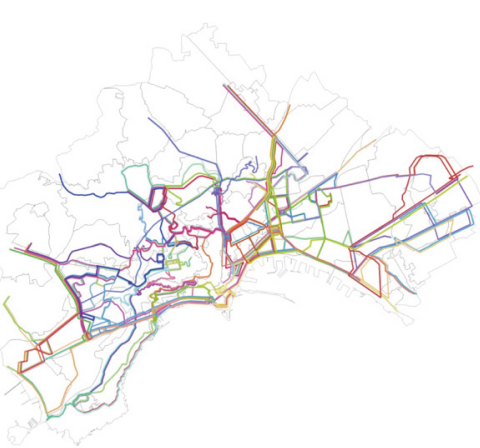

Figure 6: Bus services.

zones are only partially served by low-frequency bus lines; (e) outlying zones are only marginally served by the transit system. These differences may significantly affect the real estate values of the various zones; indeed, in cities where the transit service is more equally distributed among zones the impact on property values may be very low or very difficult to quantify.

Once all transportation system data have been gathered, we can construct a database that associates the corresponding data to each OMI zone, which we adopt as zoning since they correspond to real estate values. As for census data, all the data regarding the particular census subzones are associated with each OMI zone. Transportation data are associated with the OMI zones in the following ways: (1) a metro station is associated with a zone if it is contained in the zone or if the zone boundary is no farther than $250 \mathrm{~m}$ from the station; (2) a bus line is associated with a zone if it crosses the zone or runs along a road forming the zone boundary. In Table 3, all data associated with each OMI zone that are used to draw up the hedonic model are described, some of which are obtained with simple elaboration from starting data.

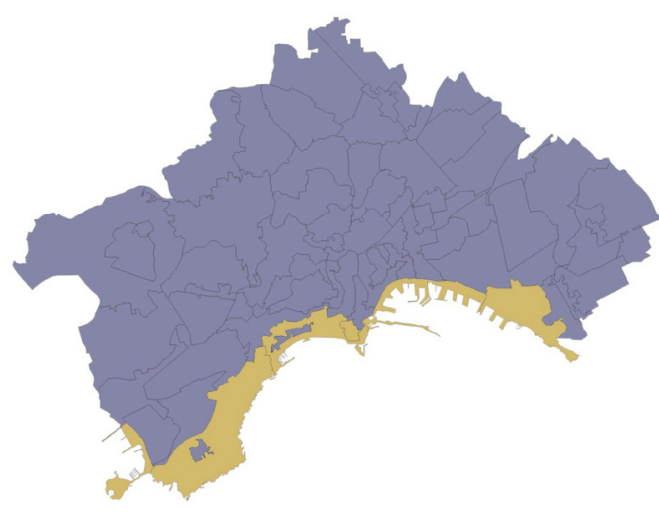

Sea

Other

FIGURE 7: Classification of OMI zones by the variable Sea.

Moreover, the zones are also classified in function of three variables referring to some important features of the area: Sea, if the zone is seafront; Hill, if the zone belongs to one of the hill districts of the city (Vomero, Posillipo, Camaldoli, and Colli Aminei); Prestige, if the zone is commonly assumed to be prestigious (Posillipo, Chiaia). Figures 7-9 report the classification of OMI zones regarding these variables.

\section{Data Analysis and Model Calibration}

Before specifying and calibrating the model, we examined the dataset in order to explore the correlation between the real estate values and the variables associated with the OMI zones. First of all, we calculated the correlation coefficient, $r_{x, y}^{j}$, between the real estate values, $y_{i}$, and each variable, $x_{i, j}$, where $i$ indicates the OMI zones and $j$ the independent variable. The correlation coefficient $r_{x, y}^{j}$ can be positive, 
TABLE 2: Bus lines.

\begin{tabular}{|c|c|}
\hline Line code & Average daily frequency [bus/h] \\
\hline 1 & 5.00 \\
\hline 2 & 3.33 \\
\hline 4 & 4.00 \\
\hline 12 & 2.07 \\
\hline 20 & 2.07 \\
\hline 128 & 2.22 \\
\hline 130 & 3.00 \\
\hline 132 & 2.50 \\
\hline 139 & 2.72 \\
\hline 140 & 3.53 \\
\hline 147 & 3.33 \\
\hline 150 & 2.73 \\
\hline 151 & 5.00 \\
\hline 154 & 2.86 \\
\hline 168 & 3.75 \\
\hline 178 & 2.14 \\
\hline 180 & 1.67 \\
\hline 181 & 3.33 \\
\hline 182 & 2.61 \\
\hline 183 & 1.94 \\
\hline 184 & 3.00 \\
\hline 185 & 2.61 \\
\hline 191 & 2.73 \\
\hline 192 & 3.00 \\
\hline 193 & 1.18 \\
\hline 194 & 2.61 \\
\hline 195 & 2.50 \\
\hline 201 & 3.75 \\
\hline 202 & 3.16 \\
\hline 203 & 2.61 \\
\hline 503 & 1.88 \\
\hline 640 & 2.40 \\
\hline Alibus & 2.86 \\
\hline $\mathrm{Cl}$ & 1.94 \\
\hline $\mathrm{C} 12$ & 2.73 \\
\hline $\mathrm{C} 13$ & 2.40 \\
\hline $\mathrm{C} 14$ & 0.92 \\
\hline $\mathrm{C} 16$ & 3.53 \\
\hline C18 & 1.54 \\
\hline $\mathrm{C} 18 \mathrm{E}$ & 1.88 \\
\hline C2 & 1.76 \\
\hline C21 & 2.86 \\
\hline C24 & 1.20 \\
\hline C25 & 2.40 \\
\hline C27 & 2.07 \\
\hline C31 & 2.14 \\
\hline C33 & 2.50 \\
\hline C33E & 2.50 \\
\hline C36 & 1.20 \\
\hline C38 & 1.62 \\
\hline C40 & 2.22 \\
\hline C41 & 2.07 \\
\hline C44 & 2.07 \\
\hline C5 & 0.97 \\
\hline C51 & 1.54 \\
\hline C52 & 1.54 \\
\hline C59 & 0.94 \\
\hline C6 & 2.31 \\
\hline C63 & 2.50 \\
\hline
\end{tabular}

TABLE 2: Continued.

\begin{tabular}{lc}
\hline Line code & Average daily frequency [bus/h] \\
\hline C65 & 2.22 \\
C68 & 2.31 \\
C76 & 2.31 \\
C91 & 2.00 \\
C94 & 1.30 \\
C96 & 1.36 \\
C98 & 1.13 \\
C99 & 1.71 \\
E1 & 2.14 \\
E2 & 2.31 \\
E6 & 1.62 \\
R2 & 6.67 \\
R4 & 5.00 \\
R5 & 2.07 \\
R6 & 4.00 \\
R7 & 2.40 \\
V1 & 1.25 \\
\hline
\end{tabular}

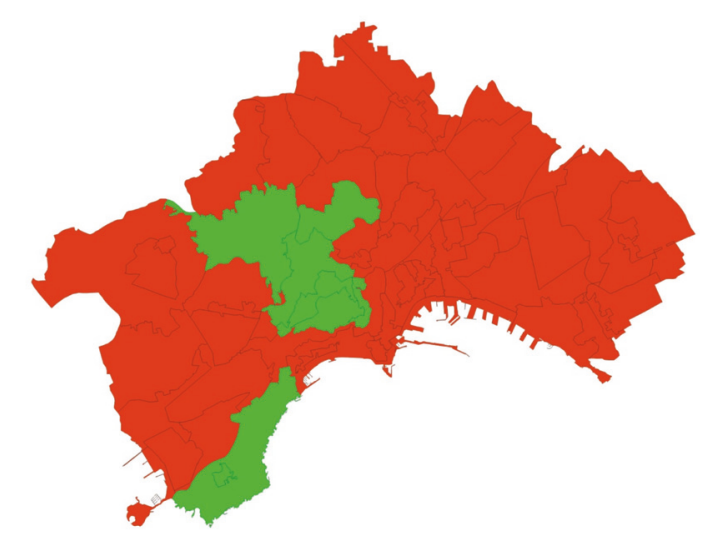

Hill

No hill

Figure 8: Classification of OMI zones by the variable Hill.

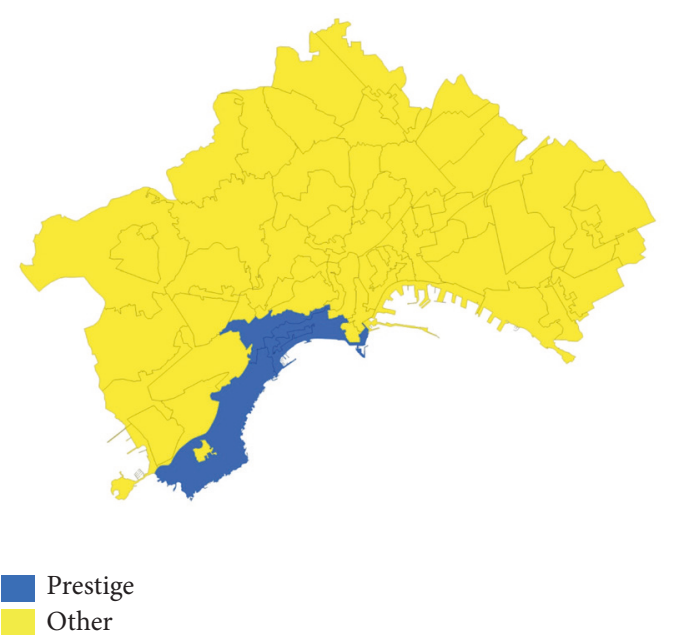

Figure 9: Classification of OMI zones by the variable Prestige. 
between 0 and 1 , or negative, between -1 and 0 , and the more its value is proximal to $1[-1]$, the higher the positive [negative] correlation is between the variables. In Table 4, the values of the correlation coefficient for each independent variable are reported. The variables Pop, Surface, $B D \_1, B D \_2$, $B D \_3, B D \_4$, and Retail_emp were not considered since they were used only for calculating other variables; the variable rural was not considered since in these areas there are no real estate values available.

Upon analysing the results, it can be noted that density is not at all correlated with real estate values (the value is very close to 0); probably, it is due to the almost equal (high) density in all zones. As regards the other variables, only certain variables presented a significant correlation $\left(r^{j}{ }_{x, y}>0.5[<-0.5]\right)$; these variables are HF_rail_st, Central, Suburban, Hill, and Prestige. It is worth noting that low-frequency railway stations are not correlated to real estate values: the value is very low, in absolute value, and even negative. We may assume that all variables with an absolute value of the correlation coefficient lower than 0.25 are not correlated with property values and, then, are not useful as explanatory variables. This first analysis highlights that the HF_rail_st variable is highly correlated with real estate values (it presents the maximum absolute value of the correlation coefficient). The correlation between possible explanatory variables is examined, reporting the correlation coefficient matrix in Table 5. Examining the matrix, a strong (negative) correlation is, obviously, between variables \%BD_3 and \%BD_1_2, since one is nearly complementary to the other; in the specification of the model, both variables will not be jointly considered. The other variables highly correlated are HF_rail_st versus Central (0.69), since in central areas there are more metro stations, and Suburban versus CF_bus (-0.55) since buses cover almost equally the other areas except for the suburban ones, where the transit service is very marginal. However, about these other correlations, the calibration of the model and, in particular, the $t$-stat tests will be able to verify if the variables are significant even if considered jointly in the model.

Starting from this preliminary analysis, we formulated and calibrated a hedonic linear regression model (LRM) for estimating real estate values. The general formulation of the model is the following:

$$
\begin{aligned}
E(Y \mid X)= & \beta_{0}+\beta_{1} X_{1}+\beta_{2} X_{2}+\cdots+\beta_{j} X_{j}+\cdots \\
& +\beta_{p} X_{p},
\end{aligned}
$$

where $E(Y \mid X)$ is the expected value of the dependent variable $Y$, in our case the real estate value (REV) of a zone, conditional upon the terms on the right side of equation, $X_{j}$, which are the independent variables; $\beta_{0}$ is the intercept, which is a parameter invariant with the values assumed by theindependent variables, $X_{j} ; \beta_{j}$ are the parameters (or coefficients) of the model, which have to be calibrated; $X_{j}$ are the independent variables.

This model has to be specified (the independent variables $X_{j}$ to be considered in the model have to be identified) and calibrated (the values of parameters $\beta s$ that are best able to reproduce the observed values of $Y$ have to be estimated).
We assume that the 60 real estate values, $y_{i}$, corresponding to the 60 OMI zones, for which the data are available, are the observed data that we collect in a vector $\mathbf{Y}$. The values of independent variables assumed in correspondence of each observation, which are usually called predictors, $x_{i, j}$, are collected in a matrix $\mathbf{X}$; there are always 60 rows in this matrix, while the number of columns depends on the number of model parameters. We also introduce the vector of the regression coefficients, $\boldsymbol{\beta}$, and the vector of statistical errors, e. Vectors and the matrix are reported below, where subscript $p$ indicates the number of parameters:

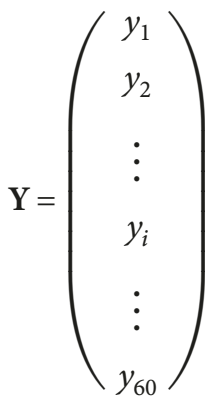

$\mathbf{X}=\left(\begin{array}{ccccccc}1 & x_{1,1} & x_{1,2} & \cdots & x_{1, j} & \cdots & x_{1, p} \\ 1 & x_{2,1} & x_{2,2} & \cdots & x_{2, j} & \cdots & x_{2, p} \\ \vdots & \vdots & \vdots & \vdots & \vdots & \vdots & \vdots \\ 1 & x_{i, 1} & x_{i, 2} & \cdots & x_{i, j} & \cdots & x_{i, p} \\ \vdots & \vdots & \vdots & \vdots & \vdots & \vdots & \vdots \\ 1 & x_{60,1} & x_{60,2} & \cdots & x_{60, j} & \cdots & x_{60, p}\end{array}\right)$

$$
\boldsymbol{\beta}=\left(\begin{array}{c}
\beta_{0} \\
\beta_{1} \\
\beta_{2} \\
\vdots \\
\beta_{j} \\
\vdots \\
\beta_{p}
\end{array}\right)
$$

$$
\mathbf{e}=\left(\begin{array}{c}
e_{1} \\
e_{2} \\
\vdots \\
e_{i} \\
\vdots \\
e_{60}
\end{array}\right)
$$

Adopting this matrix notation, the multiple linear regression model can be written as 
TABLE 3: Data.

\begin{tabular}{|c|c|c|c|}
\hline Name & Type & Unit of measurement & Description \\
\hline OMI & Alphanumeric & - & The code of the zone as provided by the OMI database \\
\hline Med_REV & Integer & $€$ & The median real estate value as provided by the OMI database \\
\hline Pop & Integer & Inhabitants & Population in the OMI zone \\
\hline Area & Real number & $\mathrm{Km}^{2}$ & Surface area of the OMI zone \\
\hline Density & Real number & Inhabitants $/ \mathrm{km}^{2}$ & Population density in the OMI zone \\
\hline BD_1 & Integer & Number of buildings & $\begin{array}{c}\text { Number of buildings with a "very good" conservation state in } \\
\text { the OMI zone }\end{array}$ \\
\hline BD_2 & Integer & Number of buildings & $\begin{array}{c}\text { Number of buildings with a "good" conservation state in the } \\
\text { OMI zone }\end{array}$ \\
\hline BD_3 & Integer & Number of buildings & $\begin{array}{l}\text { Number of buildings with a "medium" conservation state in the } \\
\text { OMI zone }\end{array}$ \\
\hline BD_4 & Integer & Number of buildings & $\begin{array}{c}\text { Number of buildings with a "poor" conservation state in the } \\
\text { OMI zone }\end{array}$ \\
\hline \% BD_1 & Percentage & $\%$ & $\begin{array}{c}\text { Percentage of buildings with a "very good" conservation state in } \\
\text { the OMI zone }\end{array}$ \\
\hline \% BD_2 & Percentage & $\%$ & $\begin{array}{l}\text { Percentage of buildings with a "good" conservation state in the } \\
\text { OMI zone }\end{array}$ \\
\hline$\%$ BD_3 & Percentage & $\%$ & $\begin{array}{c}\text { Percentage of buildings with a "medium" conservation state in } \\
\text { the OMI zone }\end{array}$ \\
\hline \% BD_4 & Percentage & $\%$ & $\begin{array}{c}\text { Percentage of buildings with a "poor" conservation state in the } \\
\text { OMI zone }\end{array}$ \\
\hline$\%$ BD_1_2 & Percentage & $\%$ & $\begin{array}{l}\text { Percentage of buildings with a "very good" or "good" } \\
\text { conservation state in the OMI zone }\end{array}$ \\
\hline Retail_emp & Integer & Employees & Employees in retail businesses in the OMI zone \\
\hline Retail_emp_d & Real number & Employees $/ \mathrm{km}^{2}$ & Density of employees in retail businesses in the OMI zone \\
\hline HF_rail_st & Integer & Stations & $\begin{array}{c}\text { Number of high-frequency ( } \geq 6.00 \text { trains/h) railway stations } \\
\text { assigned to the OMI zone }\end{array}$ \\
\hline LF_rail_st & Integer & Stations & $\begin{array}{c}\text { Number of low-frequency }(<6.00 \text { trains/h) railway stations } \\
\text { assigned to the OMI zone }\end{array}$ \\
\hline CF_bus & Real number & bus/h & Cumulated frequency of all bus lines assigned to the OMI zone \\
\hline Central & Boolean & $0 / 1$ & 1 if the zone is classified as "central" in the OMI database \\
\hline Semicentral & Boolean & $0 / 1$ & 1 if the zone is classified as "semicentral" in the OMI database \\
\hline Peripheral & Boolean & $0 / 1$ & 1 if the zone is classified as "peripheral" in the OMI database \\
\hline Suburban & Boolean & $0 / 1$ & 1 if the zone is classified as "suburban" in the OMI database \\
\hline Rural & Boolean & $0 / 1$ & 1 if the zone is classified as "rural" in the OMI database \\
\hline Hill & Boolean & $0 / 1$ & $\begin{array}{l}1 \text { if the zone belongs to one of the hill districts of the city } \\
\text { (Vomero, Posillipo, Camaldoli, Colli Aminei) }\end{array}$ \\
\hline Sea & Boolean & $0 / 1$ & 1 if the zone is seafront \\
\hline Prestige & Boolean & $0 / 1$ & $\begin{array}{l}1 \text { if the zone is commonly assumed to be prestigious (Posillipo, } \\
\text { Chiaia) }\end{array}$ \\
\hline
\end{tabular}

$$
\mathbf{Y}=\mathbf{X} \boldsymbol{\beta}+\mathbf{e}
$$

Indicating with $\mathbf{x}_{i}^{\prime}$ the $i$ th row of the matrix $\mathbf{X}$, we can write

$$
y_{i}=\mathbf{x}_{i}^{\prime} \boldsymbol{\beta}+e_{i}
$$

and hence

$$
e_{i}=y_{i}-\mathbf{x}_{i}^{\prime} \boldsymbol{\beta} \text {. }
$$

The values of coefficients $\beta$ s can be estimated with the wellknown ordinary least squares (OLS) method that minimises the sum of the square residuals:

$$
\begin{aligned}
\boldsymbol{\beta}^{\wedge} & =\operatorname{Arg}_{\boldsymbol{\beta}} \min \Sigma_{i}\left(y_{i}-\mathbf{x}_{i}{ }_{i} \boldsymbol{\beta}\right) \\
& =\operatorname{Arg}_{\boldsymbol{\beta}} \min \left[(\mathbf{Y}-\mathbf{X} \boldsymbol{\beta})^{T}(\mathbf{Y}-\mathbf{X} \boldsymbol{\beta})\right],
\end{aligned}
$$

where $\Sigma_{i}\left(y_{i}-\mathbf{x}_{i}^{\prime} \boldsymbol{\beta}\right)$ is usually indicated with $\operatorname{RSS}(\boldsymbol{\beta})$. Indicating with SYY the term $\Sigma_{i}\left(y_{i}-\bar{y}\right)^{2}$, a very important 
TABLE 4: Correlation coefficients.

\begin{tabular}{lc}
\hline Variable $v$ & $r_{x, y}^{j}$ \\
\hline Density & 0.0075 \\
\% BD_1 & 0.2137 \\
\% BD_2 & 0.2126 \\
\% BD_3 & -0.2649 \\
\% BD_4 & -0.1468 \\
\% BD_1_2 & 0.2758 \\
Retail_emp_d & 0.2956 \\
HF_rail_st & 0.7162 \\
LF_rail_st & -0.1570 \\
CF_bus & 0.3661 \\
Central & 0.6633 \\
Semicentral & 0.2407 \\
Peripheral & -0.0911 \\
Suburban & -0.6585 \\
Hill & 0.5055 \\
Sea & 0.3742 \\
Prestige & 0.6136 \\
\hline
\end{tabular}

indicator of the goodness of the model is the coefficient of determination, $R^{2}$, that is given by

$$
R^{2}=1-\left(\frac{\mathrm{RSS}}{\mathrm{SYY}}\right)
$$

This indicator measures the proportion of variability in the variables $Y_{i}$ which is explained by the linear regression model; the closer $R^{2}$ to 1 (statistical errors equal to 0 and perfect reproducibility of the phenomenon), the higher the goodness of the calibrated model.

The coefficient of determination cannot be the only indicator for evaluating the goodness of a model. Indeed, it does not always decrease (usually increases) with the number of parameters $\beta_{j}$, even if some are not actually useful for explaining the phenomenon. The other indicators that have to be used to evaluate the model are the tests of hypotheses that are able to measure whether the parameters adopted in the model are actually significant for reproducing the phenomenon. Below, we use as tests of hypotheses the F-test, obtained by the analysis of variance, and the $t$-test, regarding the significance of each independent variable. We will assume that a model is acceptable if the significance $F$ is close to 0 (at least $<0.05$ ) and if the $t$-test of each coefficient $\beta_{j}$ is higher [lower] than $t_{95}\left[-t_{95}\right]$ for positive [negative] $\beta_{j}$, where $t_{95}$ is the value of the $t$-distribution corresponding to the degrees of freedom (df) of the model with a confidence of $95 \%$.

We calibrated several models by adopting an adding method for identifying the parameters to consider in the model. Limiting the analysis only to variables where the absolute value of the correlation terms is greater than 0.25 , we started with a model with only one $\mathrm{df}$ (one parameter) considering that with the higher value of correlation coefficient (see Table 4). We calculated the corresponding values of $R^{2}$, significance $F$, and $t$-test.

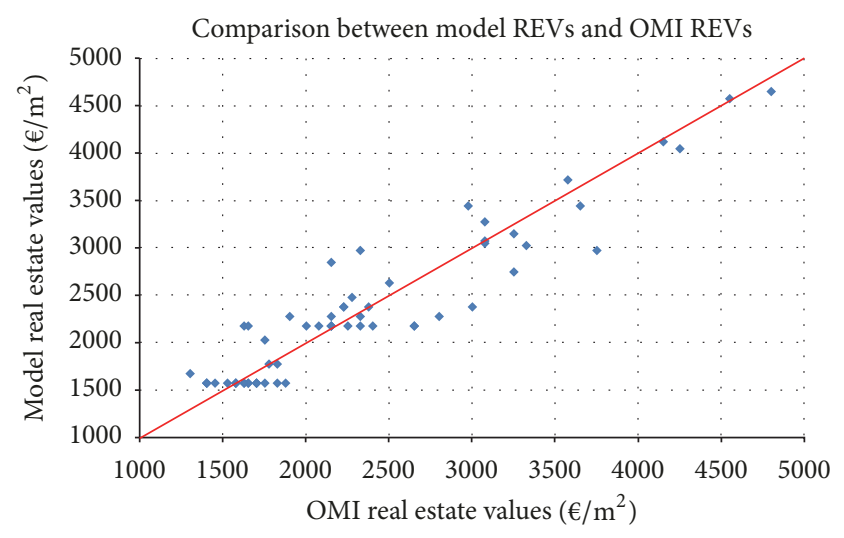

FIGURE 10: Model versus real estate values.

If the model obtained is significant in terms of $F$ and $t$ test, we add another variable to the model, the next in terms of correlation coefficient. The new added variable is maintained in the model if all significance tests are verified; otherwise it is eliminated and the procedure continues with another variable. When all variables are examined, we try to add to the model some variables previously discarded (the significance of a variable can change with different $\mathrm{df}$, since the $t_{95}$ value changes). Since $R^{2}$ always increases (or, at least, it does not change) when we add a variable, the final model obtained with this procedure will respect all significance tests and will have the highest value of $R^{2}$ of all models examined. In Table 6 , the results of the procedure are summarised: globally, we tested 12 models.

The results reported in Table 6 identify number 11 as the best model, which is as follows:

$$
\begin{aligned}
E(\mathrm{REV})= & 2179.69+100.61 * \mathrm{HF}_{\text {rail }_{\mathrm{st}}}+394.23 \\
& * \text { Central }-602.76 * \text { Suburban }+570.31 \\
& * \text { Hill }+454.50 * \text { Sea }+1046.27 \\
& * \text { Prestige. }
\end{aligned}
$$

Table 7 summarises all statistical tests and the analysis of variance (ANOVA) for the calibrated model. The residuals are reported in Table 8, while in Figure 10 the comparison is shown between the real estate values (REVs) obtained from the OMI database and the corresponding values estimated with the proposed model.

The analysis of the results shows that the model presents a good coefficient of determination (over 0.88 ) which indicates that over $88 \%$ of the variability in REVs is explained by the considered variables.

An important result to underline is that low-frequency rail stations and (low-frequency) bus lines have no significant influence on REVs. By contrast, the high-frequency rail stations have a significant and nonnegligible impact on REVs, as will be seen in the next section. The lack of significance of low-frequency services (bus and metro) on REVs is probably due to the fact that these services cover more or less all areas of the city and, then, their presence has not a practical impact on 
TABLE 5: Correlation coefficient matrix.

\begin{tabular}{lcccccccccccc}
\hline & \% BD_3 & \% BD_1_2 & Retail_emp_d & HF_rail_st & CF_bus & Central & Semicentral & Peripheral & Suburban & Hill & Sea & Prestige \\
\hline \% BD_3 & 1.00 & -0.96 & 0.20 & -0.13 & 0.02 & -0.05 & -0.20 & 0.12 & 0.10 & -0.17 & -0.08 & -0.24 \\
\% BD_1_2 & -0.96 & 1.00 & -0.19 & 0.13 & -0.10 & 0.05 & 0.13 & -0.10 & -0.07 & 0.20 & 0.09 & 0.25 \\
Retail_emp_d & 0.20 & -0.19 & 1.00 & 0.14 & 0.15 & 0.23 & -0.02 & 0.12 & -0.27 & 0.09 & 0.02 & 0.10 \\
HF_rail_st & -0.13 & 0.13 & 0.14 & 1.00 & 0.45 & 0.69 & 0.06 & -0.22 & -0.41 & 0.41 & 0.08 & 0.33 \\
CF_bus & 0.02 & -0.10 & 0.15 & 0.45 & 1.00 & 0.34 & 0.37 & -0.05 & -0.55 & 0.02 & -0.01 & 0.11 \\
Central & -0.05 & 0.05 & 0.23 & 0.69 & 0.34 & 1.00 & -0.25 & -0.26 & -0.36 & 0.19 & 0.17 & 0.39 \\
Semicentral & -0.20 & 0.13 & -0.02 & 0.06 & 0.37 & -0.25 & 1.00 & -0.29 & -0.40 & 0.27 & -0.01 & 0.02 \\
Peripheral & 0.12 & -0.10 & 0.12 & -0.22 & -0.05 & -0.26 & -0.29 & 1.00 & -0.42 & -0.10 & -0.02 & -0.15 \\
Suburban & 0.10 & -0.07 & -0.27 & -0.41 & -0.55 & -0.36 & -0.40 & -0.42 & 1.00 & -0.30 & -0.10 & -0.20 \\
Hill & -0.17 & 0.20 & 0.09 & 0.41 & 0.02 & 0.19 & 0.27 & -0.10 & -0.30 & 1.00 & 0.06 & 0.09 \\
Sea & -0.08 & 0.09 & 0.02 & 0.08 & -0.01 & 0.17 & -0.01 & -0.02 & -0.10 & 0.06 & 1.00 & 0.40 \\
Prestige & -0.24 & 0.25 & 0.10 & 0.33 & 0.11 & 0.39 & 0.02 & -0.15 & -0.20 & 0.09 & 0.40 & 1.00 \\
\hline
\end{tabular}

TABLE 6: Models.

\begin{tabular}{|c|c|c|c|c|c|c|c|c|c|c|c|c|}
\hline & 1 & 2 & 3 & 4 & 5 & 6 & 7 & 8 & 9 & 10 & 11 & 12 \\
\hline \% BD_3 & & & & & & & & & & $\mathrm{x}$ & & \\
\hline \% BD_1_2 & & & & & & & & & $\mathrm{x}$ & & & \\
\hline Retail_emp_d & & & & & & & & $\mathrm{x}$ & & & & $\mathrm{x}$ \\
\hline CF_bus & & & & & & $\mathrm{x}$ & & & & & & \\
\hline HF_rail_st & $\mathrm{x}$ & $\mathrm{x}$ & $\mathrm{x}$ & $\mathrm{x}$ & $\mathrm{x}$ & $\mathrm{x}$ & $\mathrm{x}$ & $\mathrm{x}$ & $\mathrm{x}$ & $\mathrm{x}$ & $x$ & $\mathrm{x}$ \\
\hline Central & & $\mathrm{x}$ & & & & & & & & & $x$ & $\mathrm{x}$ \\
\hline Suburban & & & $\mathrm{x}$ & $\mathrm{x}$ & $\mathrm{x}$ & $\mathrm{x}$ & $\mathrm{x}$ & $\mathrm{x}$ & $\mathrm{x}$ & $\mathrm{x}$ & $x$ & $\mathrm{x}$ \\
\hline Hill & & & & & $\mathrm{x}$ & $\mathrm{x}$ & $\mathrm{x}$ & $\mathrm{x}$ & $\mathrm{x}$ & $\mathrm{x}$ & $x$ & $\mathrm{x}$ \\
\hline Sea & & & & & & & $\mathrm{x}$ & $\mathrm{x}$ & $\mathrm{x}$ & $\mathrm{x}$ & $x$ & $\mathrm{x}$ \\
\hline Prestige & & & & $\mathrm{x}$ & $\mathrm{x}$ & $\mathrm{x}$ & $\mathrm{x}$ & $\mathrm{x}$ & $\mathrm{x}$ & $\mathrm{x}$ & $x$ & $\mathrm{x}$ \\
\hline df & 1 & 2 & 2 & 3 & 4 & 5 & 5 & 6 & 6 & 6 & 6 & 7 \\
\hline$t_{95}$ & 6.314 & 2.920 & 2.920 & 2.353 & 2.132 & 2.015 & 2.015 & 1.943 & 1.943 & 1.943 & 1.943 & 1.895 \\
\hline$R^{2}$ & 0.513 & 0.567 & 0.672 & 0.808 & 0.846 & 0.849 & 0.868 & 0.876 & 0.872 & 0.871 & 0.883 & 0.889 \\
\hline Signif. $F$ & $\cong 0$ & $\cong 0$ & $\cong 0$ & $\cong 0$ & $\cong 0$ & $\cong 0$ & $\cong 0$ & $\cong 0$ & $\cong 0$ & $\cong 0$ & $\cong 0$ & $\cong 0$ \\
\hline$t$-stat ${ }_{0}$ & 21.237 & 22.271 & 22.227 & 28.165 & 29.918 & 20.252 & 30.945 & 24.713 & 13.981 & 18.838 & 32.288 & 25.867 \\
\hline$t$-stat ${ }_{1}$ & 7.816 & 4.097 & 6.429 & 6.258 & 5.285 & -0.994 & 5.895 & 1.932 & 1.359 & -1.084 & 3.292 & 1.605 \\
\hline$t$-stat 2 & & 2.678 & -5.249 & -6.293 & -6.291 & 5.240 & -6.578 & 6.003 & 5.964 & 5.919 & 2.678 & 3.462 \\
\hline$t$-stat 3 & & & & 6.304 & 3.706 & -5.948 & 3.811 & -6.112 & -6.671 & -6.573 & -6.576 & 2.425 \\
\hline$t$-stat 4 & & & & & 7.210 & 3.204 & 2.955 & 3.898 & 3.524 & 3.624 & 4.379 & -6.172 \\
\hline$t$-stat ${ }_{5}$ & & & & & & 7.039 & 5.877 & 3.082 & 3.005 & 2.981 & 2.904 & 4.397 \\
\hline$t$-stat 6 & & & & & & & & 5.932 & 5.458 & 5.529 & 5.626 & 3.011 \\
\hline$t$-stat & & & & & & & & & & & & 5.683 \\
\hline Sign. tests & Yes & No & Yes & Yes & Yes & No & Yes & No & No & No & Yes & No \\
\hline
\end{tabular}

property values. With the calibrated model, the lower REVs of few unserved areas are explained by the variable Suburban that, actually, regards only zones where the transit service is very scarce or absent.

\section{Impact of the Naples Metro System on Real Estate Values and Estimation of External Benefits}

With the model calibrated in the previous section it is possible to estimate the impact of the Naples metro system on REVs and the corresponding external benefits. The predicted contribution of high-frequency rail stations to REVs is reported in Table 9 for each OMI zone; the same table also reports the percentages of this contribution. The percentage contributions for areas containing at least one high-frequency rail station are summarised in Figure 11, while Figure 12 reports the absolute values of the contributions. It can be noted that the contribution to REVs is significant for many zones: for two zones it is higher than $20 \%$, for nine other zones it is higher than $10 \%$, and for nine others it is higher than $5 \%$.

For estimating the corresponding external benefits, some hypotheses have to be assumed. From the ISTAT census data on total areas of residential buildings and on the number 
TABLE 7: Statistical tests for model 11.

\begin{tabular}{|c|c|c|c|c|c|c|}
\hline \multicolumn{7}{|c|}{ Regression statistics } \\
\hline Multiple $R$ & 0.940 & & & & & \\
\hline$R^{2}$ & 0.883 & & & & & \\
\hline Adjusted $R^{2}$ & 0.870 & & & & & \\
\hline Standard error & 304.246 & & & & & \\
\hline Observations & 60 & & & & & \\
\hline ANOVA & $\mathrm{df}$ & SS & MS & $F$ & Significance $F$ & \\
\hline Regression & 6 & 37198377 & 6199729 & 66.976 & $5.61 E-23$ & \\
\hline Residual & 53 & 4905988 & 92565.81 & & & \\
\hline \multirow[t]{2}{*}{ Total } & 59 & 42104365 & & & & \\
\hline & Coefficients & Standard error & $t$-stat & $p$ value & Lower 95\% & Upper $95 \%$ \\
\hline Intercept & 2179.69 & 67.51 & 32.288 & $1.56 E-36$ & 2044.29 & 2315.10 \\
\hline HF_rail_st & 100.61 & 30.57 & 3.292 & 0.001776 & 39.30 & 161.92 \\
\hline Central & 394.23 & 147.24 & 2.678 & 0.009851 & 98.91 & 689.55 \\
\hline Suburban & -602.76 & 91.67 & -6.576 & $2.17 E-08$ & -786.62 & -418.90 \\
\hline Hill & 570.31 & 130.23 & 4.379 & $5.64 E-05$ & 309.11 & 831.52 \\
\hline Sea & 454.50 & 156.48 & 2.904 & 0.005354 & 140.64 & 768.36 \\
\hline Prestige & 1046.27 & 185.98 & 5.626 & $7.09 E-07$ & 673.23 & 1419.30 \\
\hline
\end{tabular}

of buildings belonging to different classes of "conservation state," we may calculate the area $\left(\mathrm{m}^{2}\right)$ of residential buildings attributable to each class. Regarding the OMI REVs, the minimum and maximum values are available; we assume that the ISTAT "very good" classification corresponds to an expected REV equal to the maximum OMI REV, while the "poor" classification corresponds to the minimum OMI REV. The other two classes correspond to a linear interpolation of the two extreme data, assuming uniform distances between classes. Estimation of external benefits is obtained by applying the percentages estimated in Table 9 to the current REVs. In Table 10, the results of this analysis are reported for all OMI zones. Thus the external benefits, in terms of REVs, can be estimated at $€ 7.2$ billion (8.53\% of the total value of real estate assets), with an average benefit per inhabitant amounting to $€ 7,490$ or an average benefit for each residential unit $\left(100 \mathrm{~m}^{2}\right)$ of $€ 23,034$. These benefits express the increase in real estate values enjoyed by property owners; such estimates can be useful to policy-makers, to study equalisation actions, and to transportation planners, to evaluate the total benefits of interventions, including the external ones.

\section{Scenario Analyses}

The proposed model and procedure were also applied to two future scenarios; the first (Scenario 1) considers the completion of Line 1 of the metro network in Naples and of Line 6, which is now entirely closed. Currently, Line 1 (a more detailed description can be found in [46]) starts from Piscinola and ends in Piazza Garibaldi (railway central station); under the full project, instead, the line will be extended to form a circle, including Capodichino Airport and the city's business district (Centro Direzionale); Line 6 is currently closed, even if part of it is completed, and is expected to be extended as far as the metro station Municipio of Line 1. Finally, we also consider the opening of Duomo

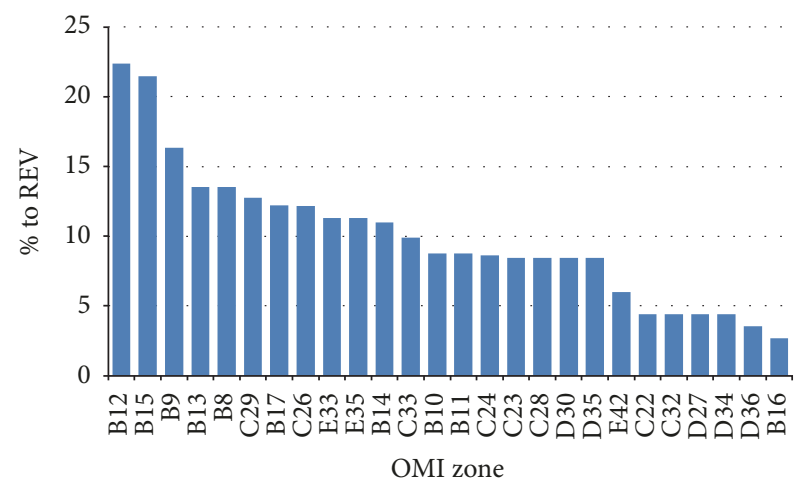

FIGURE 11: Contribution of high-frequency rail stations to real estate values (\%).

station on Line 1 which is currently under construction. For both lines, we assume that the operation will provide a daily average frequency equal to or greater than 6 trains/h. The OMI zones affected by the project are B14 ( +4 stations), E29 (+3 stations), B16, C28, D24, and E34 (+2 stations), and B18, B8, B9, D21, D22, D34, E36, E42, and E46 (+1 station); zone $\mathrm{R} 2$ is also affected, although it is excluded by the model since it only concerns the airport.

Scenario 2 considers, besides the interventions provided in Scenario 1, also an increase in the frequencies in the "Cumana" and "Circumflegrea" metro lines up to 6 trains/h. Thus their stations will become of high frequency. Compared with Scenario 0, Scenario 2 involves the following OMI zones: B14 (+5 stations), C28 (+4 stations), D23, D26, D29, D33, and E29 (+3 stations), B16, D24, E28, E34, and E39 (+2 stations), and B11, B15, B17, B18, B8, B9, D21, D22, D30, D34, E36, E42, and E46 (+1 station). The scenarios are illustrated in Figure 13.

For both scenarios, the calibrated model is used to estimate the REVs. The results concerning the contribution of 
TABLE 8: Residuals for model 11.

\begin{tabular}{|c|c|c|c|}
\hline OMI zone & OMI REV & Model REV & Residuals \\
\hline B10 & 3650 & 3446.07 & 203.93 \\
\hline B11 & 2975 & 3446.07 & -471.07 \\
\hline B12 & 4250 & 4049.73 & 200.27 \\
\hline B13 & 3750 & 2976.37 & 773.63 \\
\hline B14 & 4550 & 4577.74 & -27.74 \\
\hline B15 & 3075 & 3278.20 & -203.20 \\
\hline B16 & 3575 & 3720.80 & -145.80 \\
\hline B17 & 4150 & 4123.24 & 26.76 \\
\hline B18 & 3325 & 3028.42 & 296.58 \\
\hline B8 & 2325 & 2976.37 & -651.37 \\
\hline B9 & 3075 & 3076.98 & -1.98 \\
\hline C21 & 2250 & 2179.69 & 70.31 \\
\hline $\mathrm{C} 22$ & 2150 & 2280.30 & -130.30 \\
\hline $\mathrm{C} 23$ & 2225 & 2380.91 & -155.91 \\
\hline C24 & 4800 & 4653.21 & 146.79 \\
\hline $\mathrm{C} 25$ & 2075 & 2179.69 & -104.69 \\
\hline $\mathrm{C} 26$ & 2275 & 2481.52 & -206.52 \\
\hline C27 & 2325 & 2179.69 & 145.31 \\
\hline $\mathrm{C} 28$ & 3000 & 2380.91 & 619.09 \\
\hline C29 & 3250 & 3152.45 & 97.55 \\
\hline C30 & 2000 & 2179.69 & -179.69 \\
\hline C31 & 3250 & 2750.01 & 499.99 \\
\hline C32 & 2800 & 2280.30 & 519.70 \\
\hline C33 & 3075 & 3051.84 & 23.16 \\
\hline D21 & 1625 & 2179.69 & -554.69 \\
\hline D22 & 1650 & 2179.69 & -529.69 \\
\hline D23 & 2150 & 2179.69 & -29.69 \\
\hline D24 & 2150 & 2179.69 & -29.69 \\
\hline D25 & 2150 & 2179.69 & -29.69 \\
\hline D26 & 2400 & 2179.69 & 220.31 \\
\hline D27 & 1900 & 2280.30 & -380.30 \\
\hline D29 & 2650 & 2179.69 & 470.31 \\
\hline D30 & 2375 & 2380.91 & -5.91 \\
\hline D32 & 2500 & 2634.19 & -134.19 \\
\hline D33 & 2650 & 2179.69 & 470.31 \\
\hline D34 & 2325 & 2280.30 & 44.70 \\
\hline D35 & 2225 & 2380.91 & -155.91 \\
\hline D36 & 2150 & 2850.62 & -700.62 \\
\hline E27 & 1400 & 1576.93 & -176.93 \\
\hline E28 & 1575 & 1576.93 & -1.93 \\
\hline E29 & 1650 & 1576.93 & 73.07 \\
\hline E3 & 1700 & 1576.93 & 123.07 \\
\hline E30 & 1750 & 1576.93 & 173.07 \\
\hline E31 & 1700 & 1576.93 & 123.07 \\
\hline E32 & 1450 & 1576.93 & -126.93 \\
\hline E33 & 1825 & 1778.15 & 46.85 \\
\hline E34 & 1825 & 1576.93 & 248.07 \\
\hline
\end{tabular}


TABLE 8: Continued.

\begin{tabular}{lccc}
\hline OMI zone & OMI REV & Model REV & Residuals \\
\hline E35 & 1775 & 1778.15 & -3.15 \\
E36 & 1400 & 1576.93 & -176.93 \\
E37 & 1525 & 1576.93 & -51.93 \\
E38 & 1625 & 1576.93 & 48.07 \\
E39 & 1650 & 1576.93 & 73.07 \\
E40 & 1875 & 1576.93 & 298.07 \\
E42 & 1300 & 1677.54 & -377.54 \\
E43 & 1750 & 2031.43 & -281.43 \\
E44 & 1625 & 1576.93 & 48.07 \\
E45 & 1575 & 1576.93 & -1.93 \\
E46 & 1700 & 1576.93 & 123.07 \\
E47 & 1575 & 1576.93 & -1.93 \\
E48 & 1400 & 1576.93 & -176.93 \\
\hline
\end{tabular}

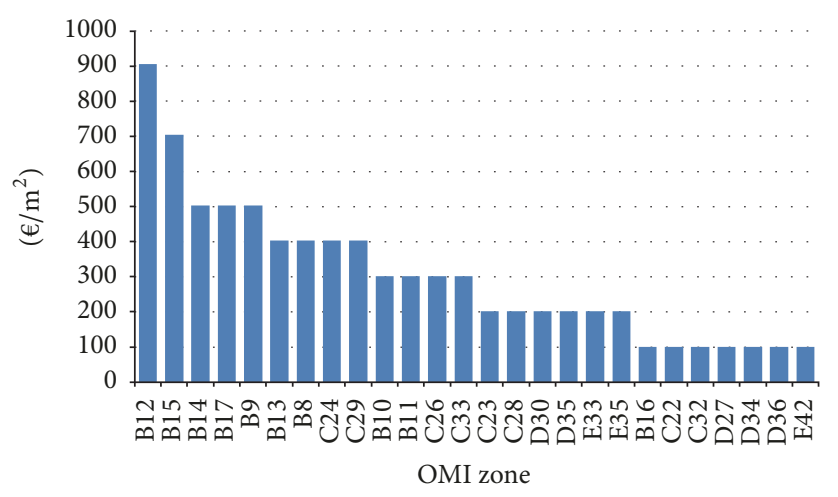

FIGURE 12: Contribution of high-frequency rail stations to real estate values $(€)$.

all scenarios to REVs are summarised in Table 11; the same results are reported in Figure 14. By contrast, Table 12 reports the estimation of external benefits. These results show that the interventions provided in Scenario 1 increase the external benefits by about 1.6 billion euros, while under Scenario 2 the benefits could increase by up to $€ 3.5$ billion with respect to Scenario 0. In Scenario 1, the external benefits increase up to $€ 9,169$ per inhabitant and $€ 28,197$ per residential unit of $100 \mathrm{~m}^{2}$; in Scenario 2 to $€ 10,662$ per inhabitant and $€ 34.084$ per residential unit of $100 \mathrm{~m}^{2}$.

\section{Conclusions}

In this paper, we specified and calibrated a hedonic model to estimate the impact of transit systems on real estate values and the corresponding external benefits for the city of Naples. The analyses led to some important conclusions regarding the case study.

High-frequency metro lines ( $\geq 6$ trains/h) produce significant impacts on real estate values, while no such correlation was found with low-frequency metro lines and bus lines. This underlines that only high-quality transit systems affect property values in Naples.

The estimated value of external benefits correlated to this aspect is high both in terms of absolute value (€7.2 billion,
$€ 7,490$ per inhabitant and $€ 23,034$ per $100 \mathrm{~m}^{2}$ residential unit) and in terms of percentage value $(8.53 \%$ of total real estate assets). In some areas, the contribution to real estate value is very high, reaching as much as $22 \%$ of the total amount. These benefits may be explicitly considered in cost-benefit analyses.

The proposed model and procedure applied to two future scenarios are able to estimate the corresponding increases in the external benefits regarding real estate values. Our results show that interventions on the network with a view to increasing the number of high-frequency metro lines may produce an appreciable increase in real estate values.

Future research will be addressed to test other approaches in the case study, considering log-linear models and hedonic spatial models and evaluating socioeconomic impacts of a single transit line on the crossed zones. Moreover, to test the procedure on other European cities, recalibrating the model as required, and to consider this approach in cost-benefit analyses will be the object of future research too.

\section{Conflicts of Interest}

The author declares that he has no conflicts of interest. 
TABLE 9: Contribution of high-frequency rail stations to real estate values.

\begin{tabular}{|c|c|c|c|}
\hline OMI zone & Model REVs & Contribution of HF_rail_st variable & $\%$ \\
\hline $\mathrm{B} 10$ & 3446.07 & 301.83 & $8.8 \%$ \\
\hline B11 & 3446.07 & 301.83 & $8.8 \%$ \\
\hline B12 & 4049.73 & 905.50 & $22.4 \%$ \\
\hline B13 & 2976.37 & 402.44 & $13.5 \%$ \\
\hline B14 & 4577.74 & 503.05 & $11.0 \%$ \\
\hline B15 & 3278.20 & 704.27 & $21.5 \%$ \\
\hline B16 & 3720.80 & 100.61 & $2.7 \%$ \\
\hline B17 & 4123.24 & 503.05 & $12.2 \%$ \\
\hline B18 & 3028.42 & 0.00 & $0.0 \%$ \\
\hline B8 & 2976.37 & 402.44 & $13.5 \%$ \\
\hline B9 & 3076.98 & 503.05 & $16.3 \%$ \\
\hline $\mathrm{C} 21$ & 2179.69 & 0.00 & $0.0 \%$ \\
\hline $\mathrm{C} 22$ & 2280.30 & 100.61 & $4.4 \%$ \\
\hline $\mathrm{C} 23$ & 2380.91 & 201.22 & $8.5 \%$ \\
\hline $\mathrm{C} 24$ & 4653.21 & 402.44 & $8.6 \%$ \\
\hline $\mathrm{C} 25$ & 2179.69 & 0.00 & $0.0 \%$ \\
\hline C26 & 2481.52 & 301.83 & $12.2 \%$ \\
\hline $\mathrm{C} 27$ & 2179.69 & 0.00 & $0.0 \%$ \\
\hline $\mathrm{C} 28$ & 2380.91 & 201.22 & $8.5 \%$ \\
\hline $\mathrm{C} 29$ & 3152.45 & 402.44 & $12.8 \%$ \\
\hline $\mathrm{C} 30$ & 2179.69 & 0.00 & $0.0 \%$ \\
\hline C31 & 2750.01 & 0.00 & $0.0 \%$ \\
\hline C32 & 2280.30 & 100.61 & $4.4 \%$ \\
\hline $\mathrm{C} 33$ & 3051.84 & 301.83 & $9.9 \%$ \\
\hline D21 & 2179.69 & 0.00 & $0.0 \%$ \\
\hline D22 & 2179.69 & 0.00 & $0.0 \%$ \\
\hline D23 & 2179.69 & 0.00 & $0.0 \%$ \\
\hline D24 & 2179.69 & 0.00 & $0.0 \%$ \\
\hline D25 & 2179.69 & 0.00 & $0.0 \%$ \\
\hline D26 & 2179.69 & 0.00 & $0.0 \%$ \\
\hline D27 & 2280.30 & 100.61 & $4.4 \%$ \\
\hline D29 & 2179.69 & 0.00 & $0.0 \%$ \\
\hline D30 & 2380.91 & 201.22 & $8.5 \%$ \\
\hline D32 & 2634.19 & 0.00 & $0.0 \%$ \\
\hline D33 & 2179.69 & 0.00 & $0.0 \%$ \\
\hline D34 & 2280.30 & 100.61 & $4.4 \%$ \\
\hline D35 & 2380.91 & 201.22 & $8.5 \%$ \\
\hline D36 & 2850.62 & 100.61 & $3.5 \%$ \\
\hline E27 & 1576.93 & 0.00 & $0.0 \%$ \\
\hline E28 & 1576.93 & 0.00 & $0.0 \%$ \\
\hline E29 & 1576.93 & 0.00 & $0.0 \%$ \\
\hline E3 & 1576.93 & 0.00 & $0.0 \%$ \\
\hline E30 & 1576.93 & 0.00 & $0.0 \%$ \\
\hline E31 & 1576.93 & 0.00 & $0.0 \%$ \\
\hline E32 & 1576.93 & 0.00 & $0.0 \%$ \\
\hline E33 & 1778.15 & 201.22 & $11.3 \%$ \\
\hline
\end{tabular}


TABLE 9: Continued.

\begin{tabular}{lccc}
\hline OMI zone & Model REVs & Contribution of HF_rail_st variable & $\%$ \\
\hline E34 & 1576.93 & 0.00 & $0.0 \%$ \\
E35 & 1778.15 & 201.22 & $11.3 \%$ \\
E36 & 1576.93 & 0.00 & $0.0 \%$ \\
E37 & 1576.93 & 0.00 & $0.0 \%$ \\
E38 & 1576.93 & 0.00 & $0.0 \%$ \\
E39 & 1576.93 & 0.00 & $0.0 \%$ \\
E40 & 1576.93 & 0.00 & $0.0 \%$ \\
E42 & 1677.54 & 100.61 & $6.0 \%$ \\
E43 & 2031.43 & 0.00 & $0.0 \%$ \\
E44 & 1576.93 & 0.00 & $0.0 \%$ \\
E45 & 1576.93 & 0.00 & $0.0 \%$ \\
E46 & 1576.93 & 0.00 & $0.0 \%$ \\
E47 & 1576.93 & 0.00 & $0.0 \%$ \\
E48 & 1576.93 & 0.00 & $0.0 \%$ \\
\hline
\end{tabular}

Scenario 1

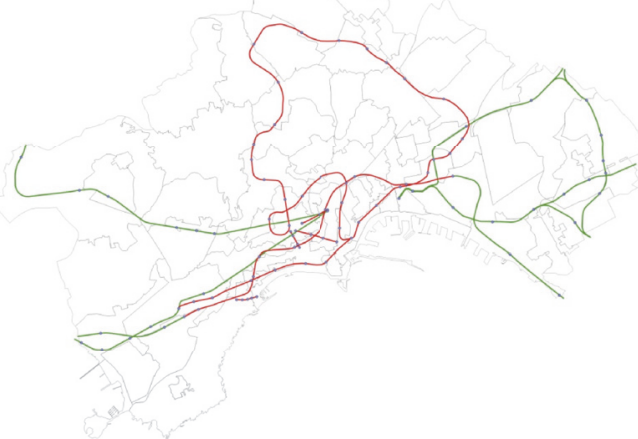

Scenario 2

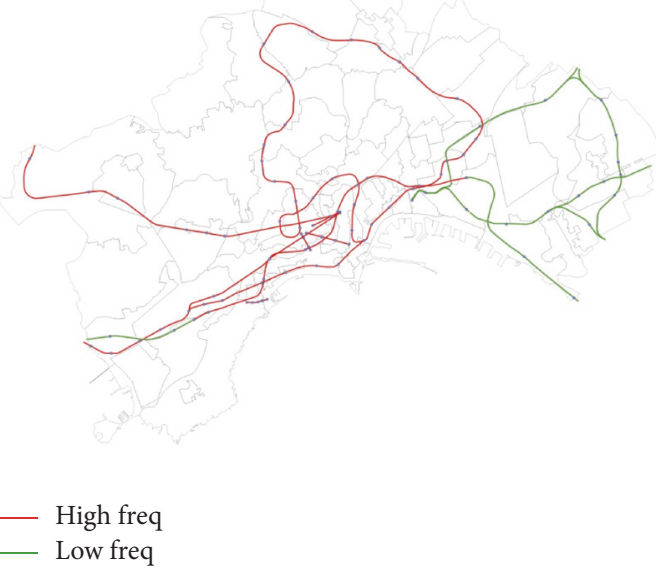

FIgURE 13: Scenarios.

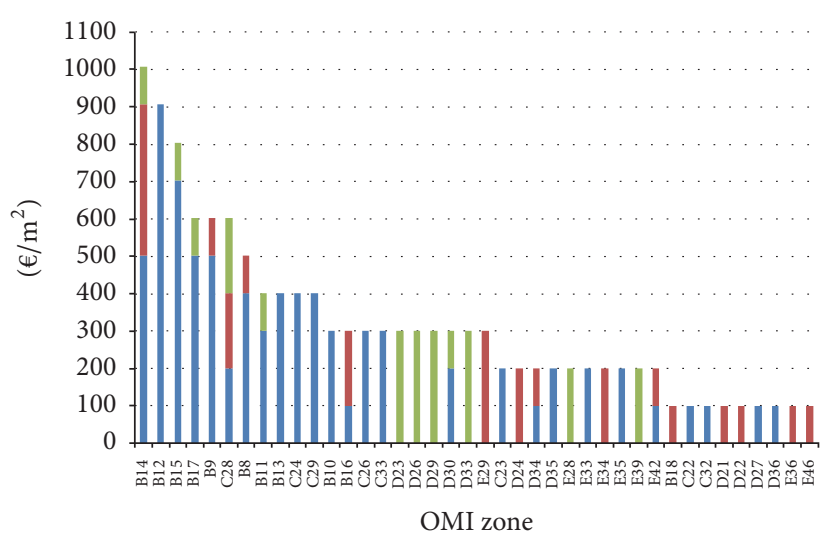

- Scenario 2

- Scenario 1

- Scenario 0

FIGURE 14: Contribution of high-frequency rail stations to real estate values for each scenario. 


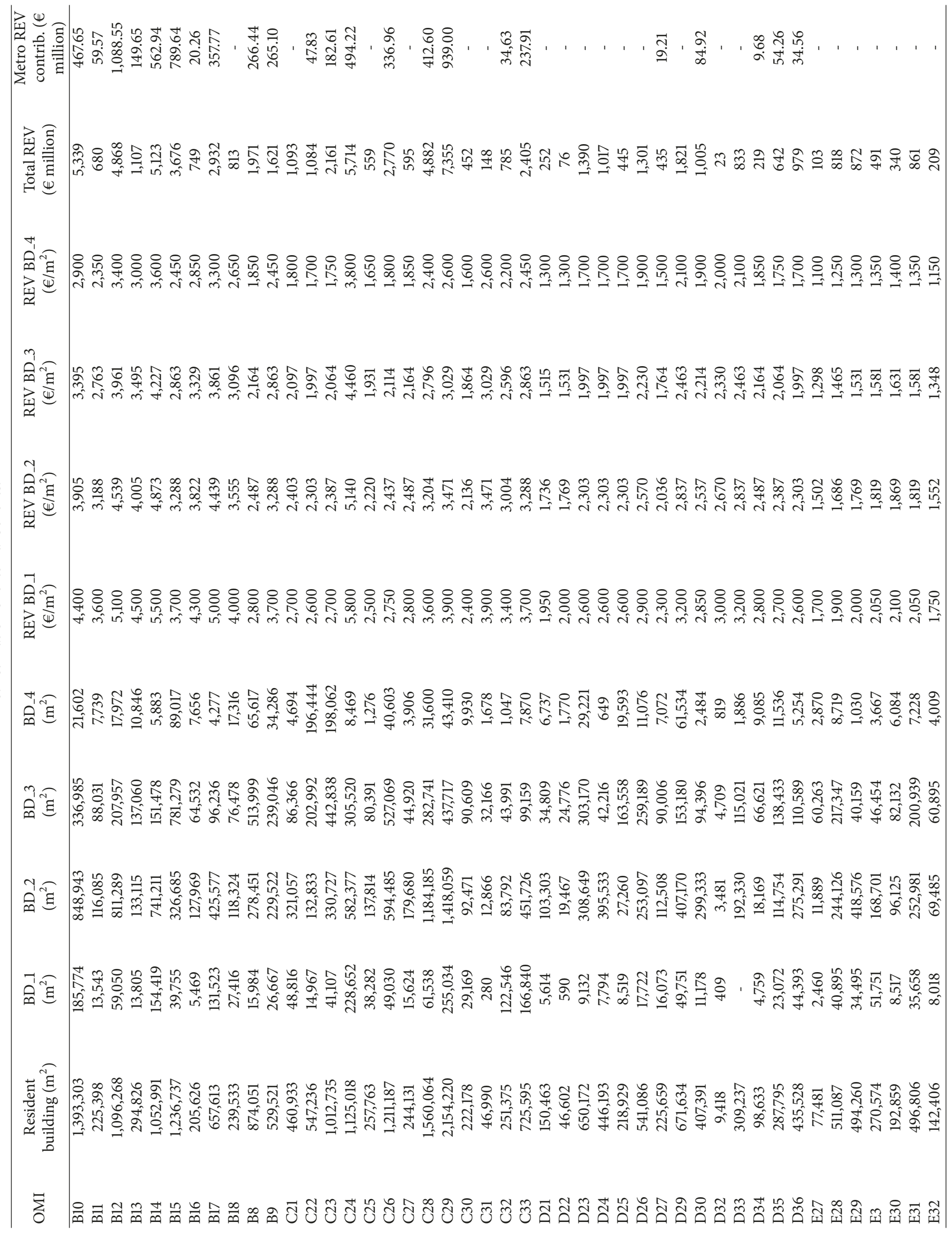




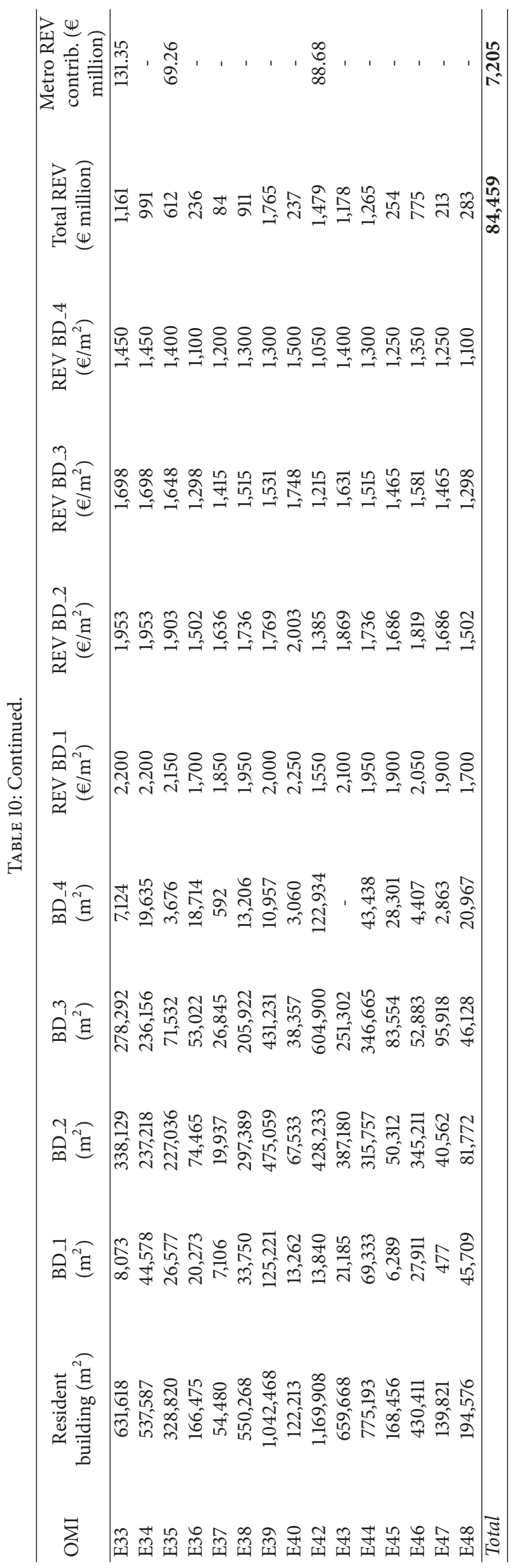




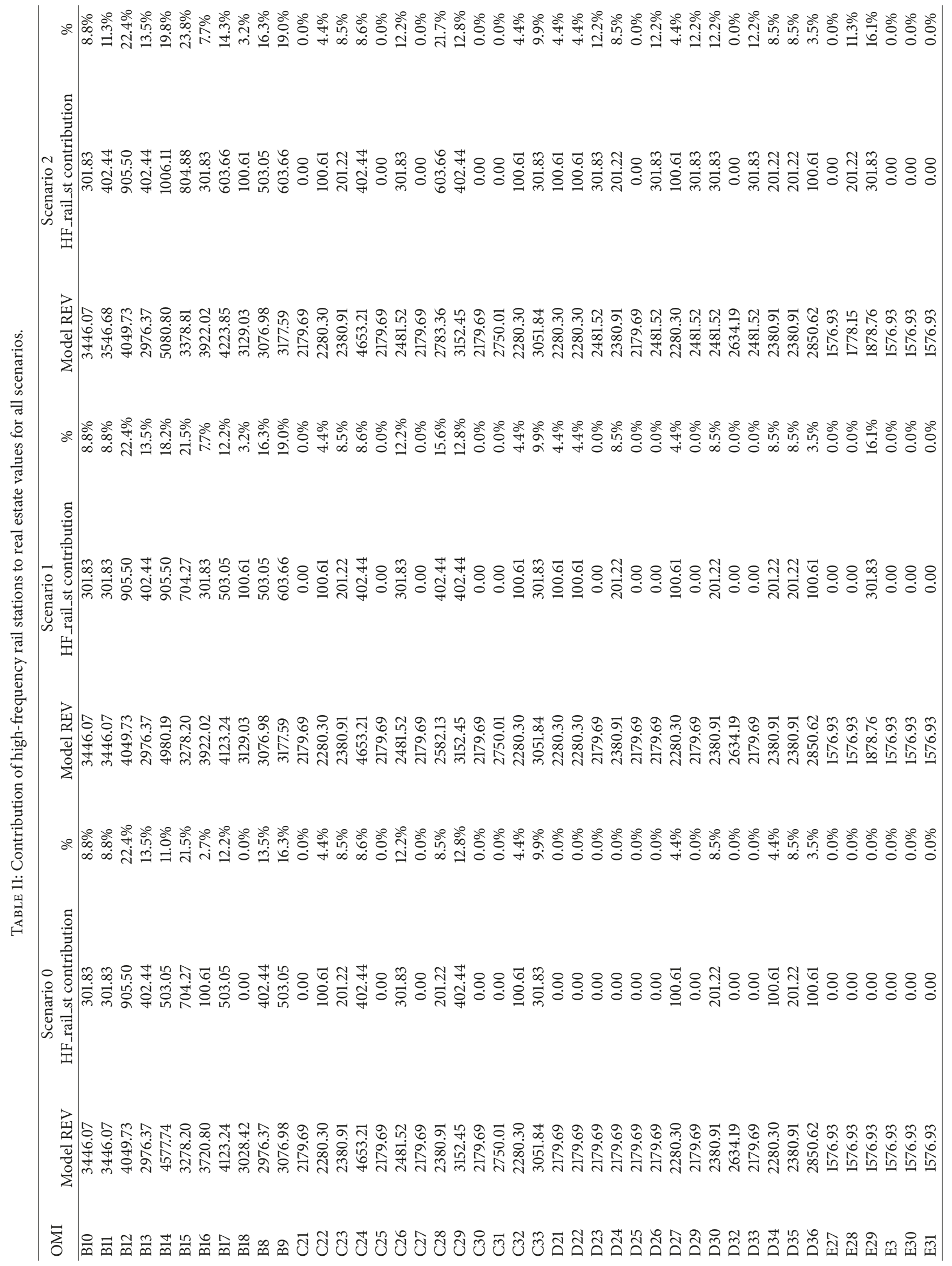




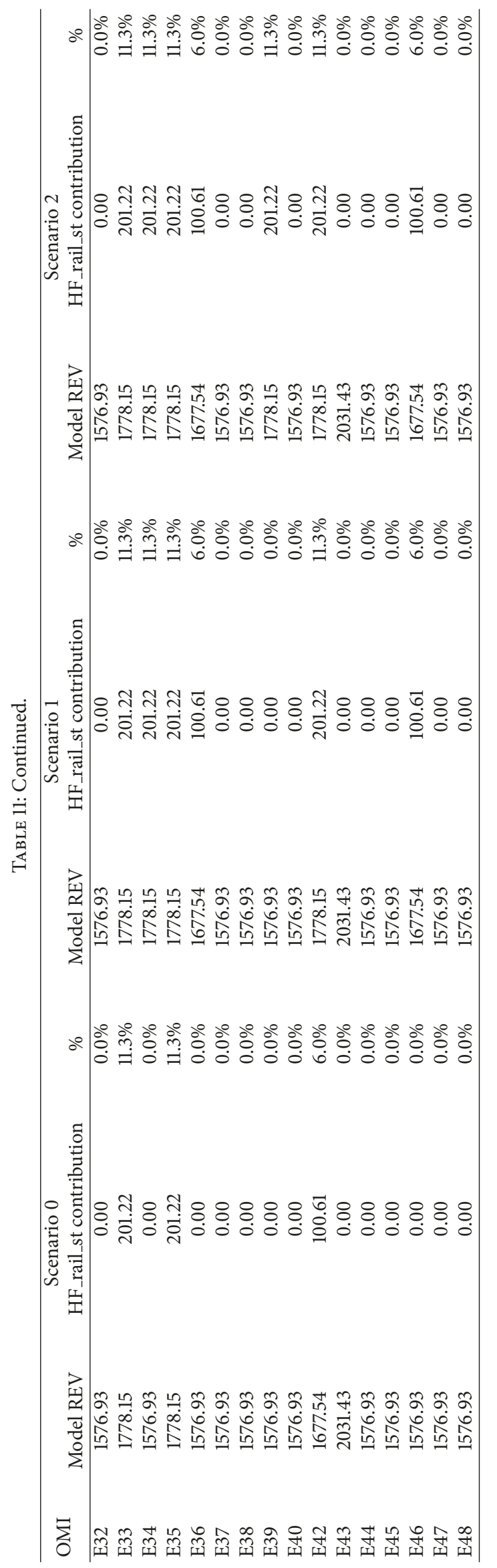




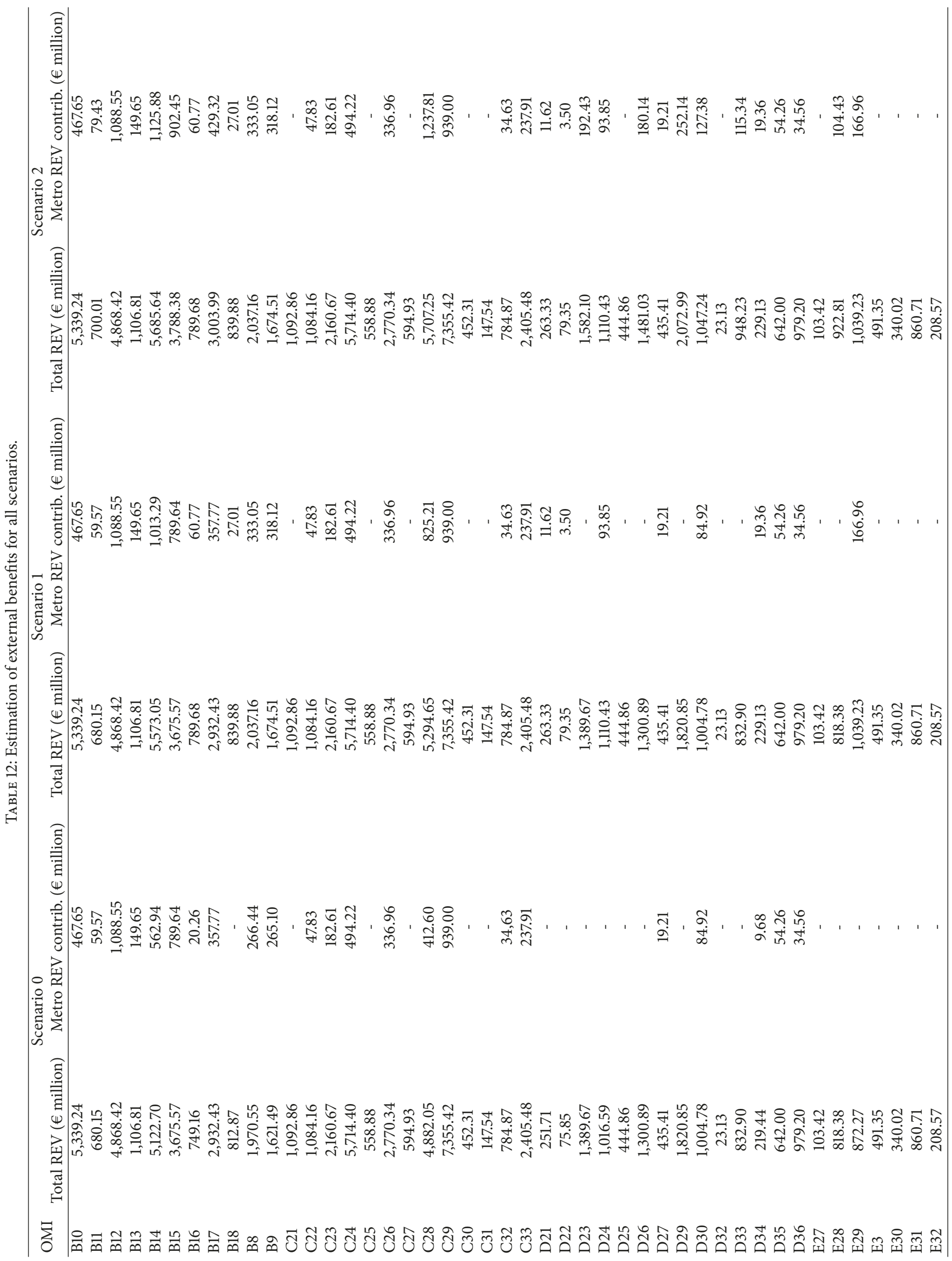




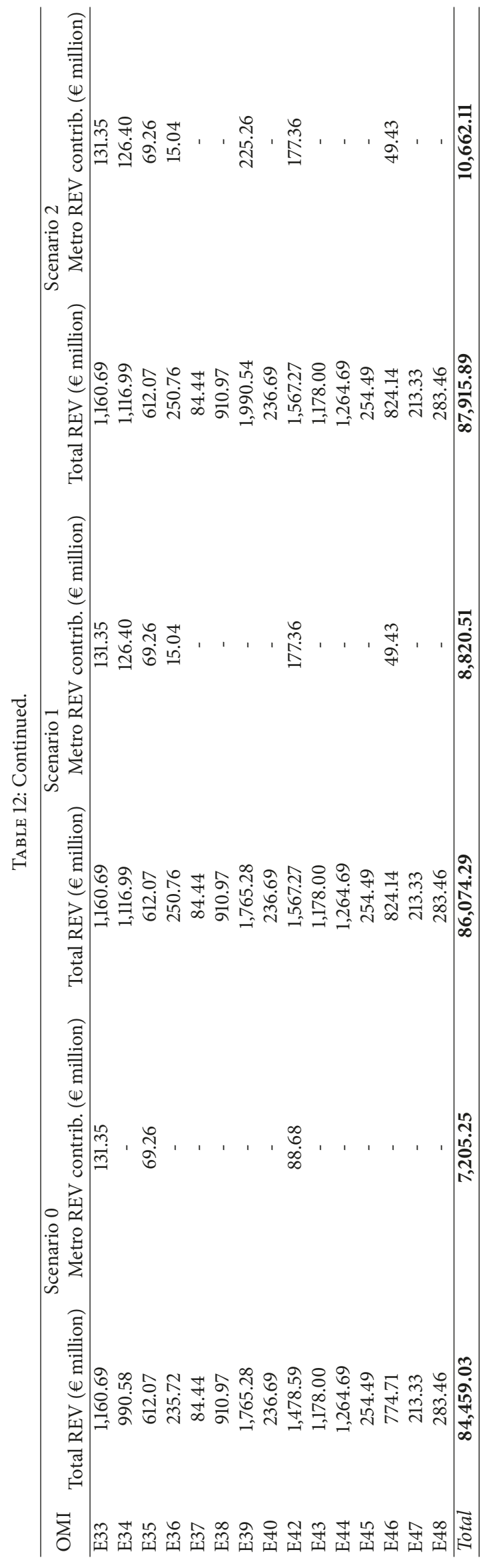




\section{Acknowledgments}

The author is grateful to Antonio Pace for his helpful collaboration in defining the transit network model.

\section{References}

[1] W. J. Baumol and W. E. Oates, The theory of environmental policy, Cambridge University Press, Cambridge, 1988.

[2] J. M. Buchanan and W. C. Stubblebine, "Externality," Economica, vol. 29, no. 116, p. 371, 1962.

[3] E. T. Verhoef, The economics of regulating road transport, Edward Elgar Publishing, 1996.

[4] D. J. Forkenbrock, "Comparison of external costs of rail and truck freight transportation," Transportation Research Part A: Policy and Practice, vol. 35, no. 4, pp. 321-337, 2001.

[5] I. Mayeres, S. Ochelen, and S. Proost, "The marginal external costs of urban transport," Transportation Research Part D: Transport and Environment, vol. 1, no. 2, pp. 111-130, 1996.

[6] E. Quinet, "A meta-analysis of Western European external costs estimates," Transportation Research Part D: Transport and Environment, vol. 9, no. 6, pp. 465-476, 2004.

[7] J. Rouwendal and E. T. Verhoef, "Basic economic principles of road pricing: From theory to applications," Transport Policy, vol. 13, no. 2, pp. 106-114, 2006.

[8] E. Verhoef, "External effects and social costs of road transport," Transportation Research Part A: Policy and Practice, vol. 28, no. 4, pp. 273-287, 1994.

[9] F. Medda, "Land value capture finance for transport accessibility: A review," Journal of Transport Geography, vol. 25, pp. 154161, 2012.

[10] H. Cremer, F. Gahvari, and N. Ladoux, "Externalities and optimal taxation," Journal of Public Economics, vol. 70, pp. 343364, 1998

[11] A. J. Auerbach and J. R. Hines Jr., "Chapter 21 Taxation and economic efficiency," Handbook of Public Economics, vol. 3, pp. 1347-1421, 2002.

[12] V. Christiansen and S. Smith, "Externality-Correcting Taxes and Regulation," The Scandinavian Journal of Economics, vol. 114, no. 2, pp. 358-383, 2012.

[13] S. Rosen, "Hedonic prices and implicit markets: product differentiation in pure competition," Journal of Political Economy, vol. 82, no. 1, pp. 34-55, 1974.

[14] C.-H. C. Bae, M.-J. Jun, and H. Park, “The impact of Seoul's subway Line 5 on residential property values," Transport Policy, vol. 10, no. 2, pp. 85-94, 2003.

[15] H. Bohman and D. Nilsson, "The impact of regional commuter trains on property values: Price segments and income," Journal of Transport Geography, vol. 56, pp. 102-109, 2016.

[16] Z. Chen and K. E. Haynes, "Impact of high speed rail on housing values: An observation from the Beijing-Shanghai line," Journal of Transport Geography, vol. 43, pp. 91-100, 2015.

[17] J. Dubé, M. Thériault, and F. Des Rosiers, "Commuter rail accessibility and house values: The case of the Montreal South Shore, Canada, 1992-2009," Transportation Research Part A: Policy and Practice, vol. 54, pp. 49-66, 2013.

[18] A. I. Kay, R. B. Noland, and S. DiPetrillo, "Residential property valuations near transit stations with transit-oriented development," Journal of Transport Geography, vol. 39, pp. 131-140, 2014.
[19] C. Mulley, L. Ma, G. Clifton, B. Yen, and M. Burke, "Residential property value impacts of proximity to transport infrastructure: An investigation of bus rapid transit and heavy rail networks in Brisbane, Australia," Journal of Transport Geography, vol. 54, pp. 41-52, 2016.

[20] F. Pagliara and E. Papa, "Urban rail systems investments: An analysis of the impacts on property values and residents' location," Journal of Transport Geography, vol. 19, no. 2, pp. 200211, 2011.

[21] K. Seo, A. Golub, and M. Kuby, "Combined impacts of highways and light rail transit on residential property values: A spatial hedonic price model for Phoenix, Arizona," Journal of Transport Geography, vol. 41, pp. 53-62, 2014.

[22] W. Sun, S. Zheng, and R. Wang, "The capitalization of subway access in home value: A repeat-rentals model with supply constraints in Beijing," Transportation Research Part A: Policy and Practice, vol. 80, pp. 104-115, 2015.

[23] T. Xu, M. Zhang, and P. T. Aditjandra, "The impact of urban rail transit on commercial property value: New evidence from Wuhan, China," Transportation Research Part A: Policy and Practice, vol. 91, pp. 223-235, 2016.

[24] H. Zhong and W. Li, "Rail transit investment and property values: An old tale retold," Transport Policy, vol. 51, pp. 33-48, 2016.

[25] G. Debrezion, E. Pels, and P. Rietveld, "The impact of railway stations on residential and commercial property value: A metaanalysis," The Journal of Real Estate Finance and Economics, vol. 35, no. 2, pp. 161-180, 2007.

[26] J. Dubé, D. Legros, M. Thériault, and F. Des Rosiers, "A spatial Difference-in-Differences estimator to evaluate the effect of change in public mass transit systems on house prices," Transportation Research Part B: Methodological, vol. 64, pp. 2440, 2014.

[27] R. Cervero and C. D. Kang, "Bus rapid transit impacts on land uses and land values in Seoul, Korea," Transport Policy, vol. 18, no. 1, pp. 102-116, 2011.

[28] J. Dubé, F. D. Rosiers, M. Thériault, and P. Dib, "Economic impact of a supply change in mass transit in urban areas: A Canadian example," Transportation Research Part A: Policy and Practice, vol. 45, no. 1, pp. 46-62, 2011.

[29] M.-J. Jun, "Redistributive effects of bus rapid transit (BRT) on development patterns and property values in Seoul, Korea," Transport Policy, vol. 19, no. 1, pp. 85-92, 2012.

[30] R. Munoz-Raskin, "Walking accessibility to bus rapid transit: Does it affect property values? The case of Bogotá, Colombia," Transport Policy, vol. 17, no. 2, pp. 72-84, 2010.

[31] J. S. Chang and D.-J. Kim, "Hedonic estimates of rail noise in Seoul," Transportation Research Part D: Transport and Environment, vol. 19, pp. 1-4, 2013.

[32] D. Efthymiou and C. Antoniou, "How do transport infrastructure and policies affect house prices and rents? Evidence from Athens, Greece," Transportation Research Part A: Policy and Practice, vol. 52, pp. 1-22, 2013.

[33] S. Brandt and W. Maennig, "Road noise exposure and residential property prices: Evidence from Hamburg," Transportation Research Part D: Transport and Environment, vol. 16, no. 1, pp. 23-30, 2011.

[34] A. Szczepańska, A. Senetra, and M. W. Pszczółkowska, "The effect of road traffic noise on the prices of residential property A case study of the polish city of Olsztyn," Transportation Research Part D: Transport and Environment, vol. 36, pp. 167177, 2015. 
[35] S. I. Mohammad, D. J. Graham, P. C. Melo, and R. J. Anderson, "A meta-analysis of the impact of rail projects on land and property values," Transportation Research Part A: Policy and Practice, vol. 50, pp. 158-170, 2013.

[36] Á. Ibeas, R. Cordera, L. Dell'Olio, P. Coppola, and A. Dominguez, "Modelling transport and real-estate values interactions in urban systems," Journal of Transport Geography, vol. 24, pp. 370-382, 2012.

[37] S. Mathur and C. Ferrell, "Measuring the impact of sub-urban transit-oriented developments on single-family home values," Transportation Research Part A: Policy and Practice, vol. 47, pp. 42-55, 2013.

[38] G. Debrezion, E. Pels, and P. Rietveld, "The impact of rail transport on real estate prices: an empirical analysis of the Dutch housing market," Urban Studies, vol. 48, no. 5, pp. 9971015, 2011.

[39] L. Anselin and N. Lozano-Gracia, "Spatial hedonic models," Palgrave Handbook of Econometrics: Volume 2: Applied Econometrics, pp. 1213-1250, 2009.

[40] D. M. Brasington and D. Hite, "Demand for environmental quality: A spatial hedonic analysis," Regional Science \& Urban Economics, vol. 35, no. 1, pp. 57-82, 2005.

[41] C. W. Kim, T. T. Phipps, and L. Anselin, "Measuring the benefits of air quality improvement: A spatial hedonic approach," Journal of Environmental Economics and Management, vol. 45, no. 1, pp. 24-39, 2003.

[42] M. Wilhelmsson, "Spatial models in real estate economics," Housing, Theory and Society, vol. 19, no. 2, pp. 92-101, 2002.

[43] E.-H. Yoo and P. C. Kyriakidis, "Area-to-point Kriging in spatial hedonic pricing models," Journal of Geographical Systems, vol. 11, no. 4, pp. 381-406, 2009.

[44] ISTAT (2011) Basi territoriali e variabili censuarie http://www .istat.it/it/archivio/104317.

[45] OMI (2016) [http//www.agenziaentrate.gov.it/wps/content/Nsilib/ Nsi/Documentazione/omi/Banche+dati/_Quotazioni+immobiliari/ - Visited 15/02/2016].

[46] L. D'Acierno, M. Botte, A. Placido, C. Caropreso, and B. Montella, "Methodology for Determining Dwell Times Consistent with Passenger Flows in the Case of Metro Services," Urban Rail Transit, vol. 3, no. 2, pp. 73-89, 2017. 


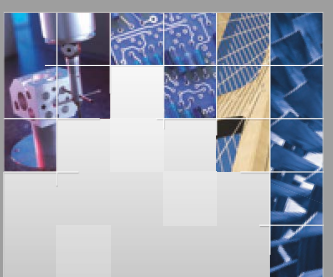

\section{Enfincering}
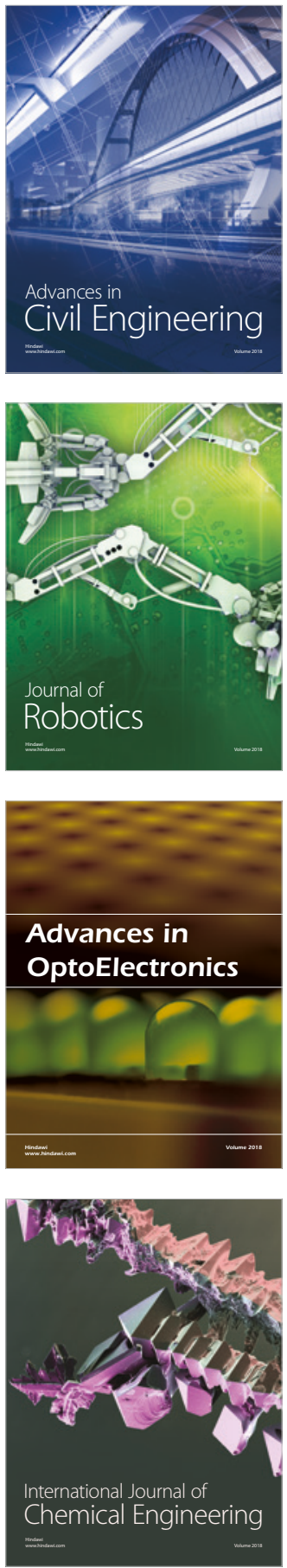

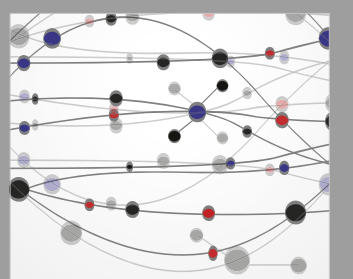

\section{Rotating \\ Machinery}

The Scientific World Journal

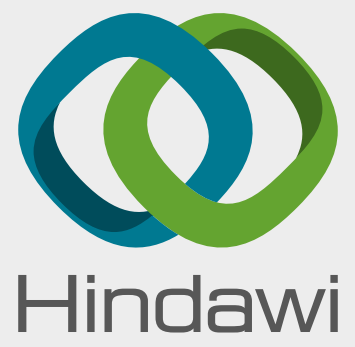

Submit your manuscripts at

www.hindawi.com
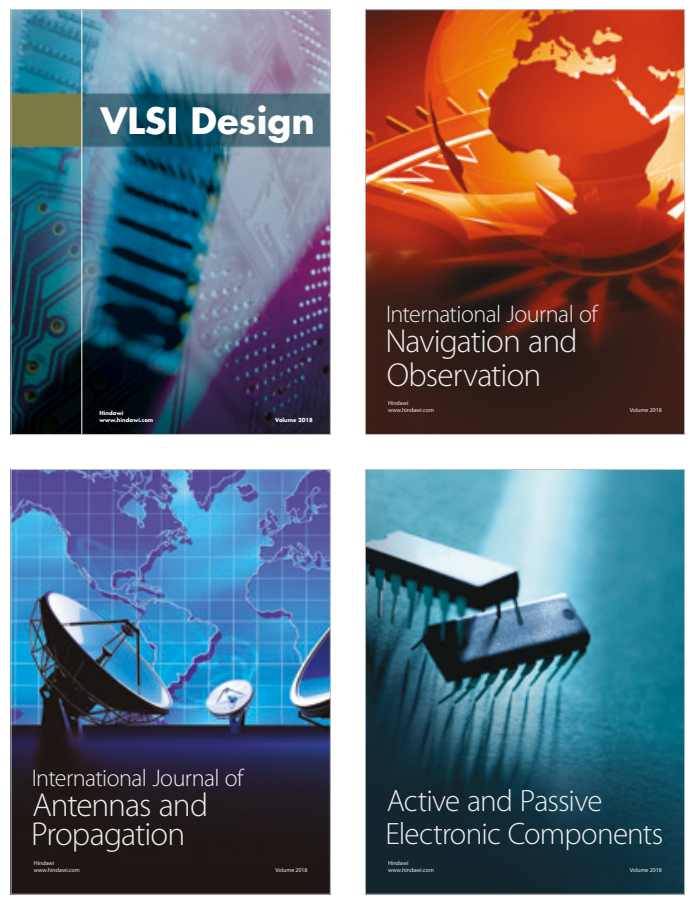
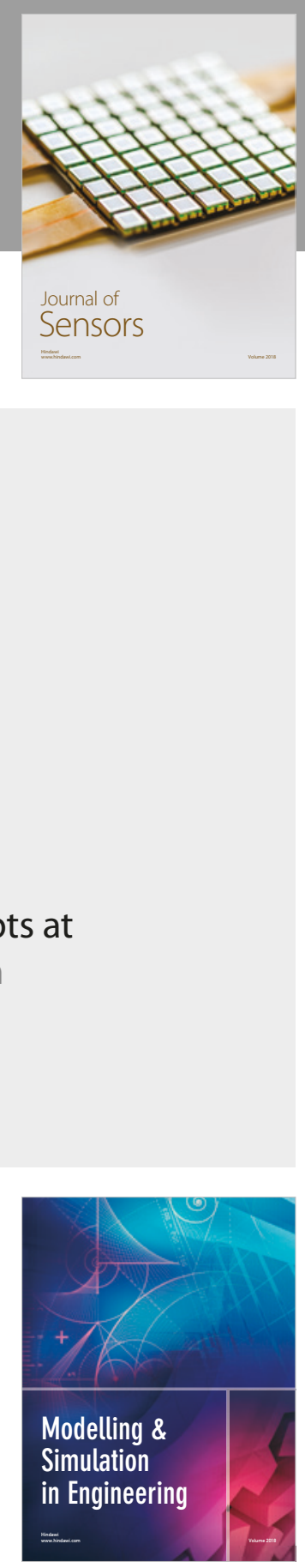

\section{Advances \\ Multimedia}
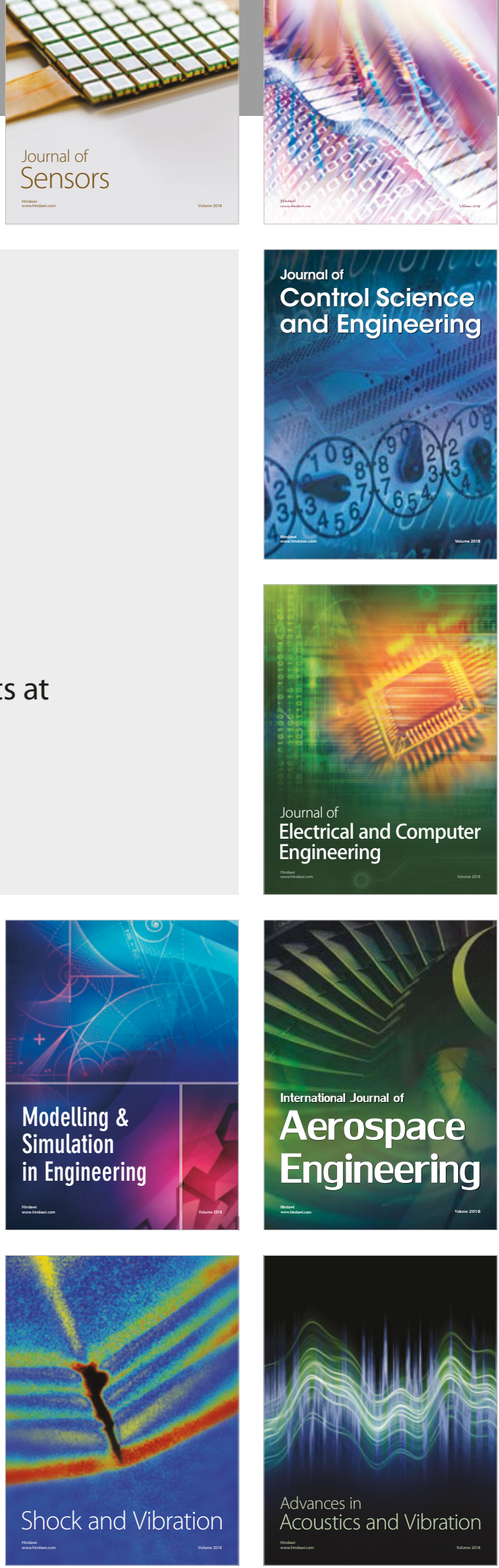